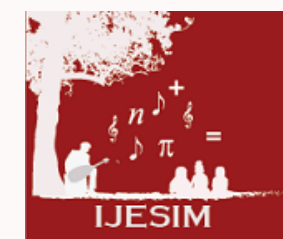

International Journal of Educational Studies in Mathematics

ISSN: 2148-5984

wWw.ijesim.com

\title{
What Are the Strategies Used by Seventh Grade Students While Solving Proportional Reasoning Problems?
}

\author{
Ramazan Avcu${ }^{1}$, Mustafa Doğan ${ }^{2}$ \\ ${ }^{1}$ Department of Elementary Education, Faculty of Education, Aksaray University, Aksaray, TURKEY \\ ${ }^{2}$ Department of Elementary Education, Faculty of Education, Yildiz Teknik University, İstanbul, TURKEY
}

ABSTRACT

The aim of this study was to investigate seventh grade students' use of solution strategies needed to solve proportional reasoning problems. A private middle school and two public middle schools of a city located in the inner region of Turkey were selected as the sample of the study. In total, 278 students (157 boys and 121 girls) took part in the study. Survey methodology was used to describe seventh grade students' proportional reasoning strategies. Proportional Reasoning Test (PRT) consisting of five open ended problems was developed by the researchers to determine students' solution strategies. Student responses to each problem were graded by the help of a rubric. Besides, the correct solution strategies used by the students were coded by considering pre-existing proportional reasoning strategies in the mathematics education literature. Analysis of students' correct responses showed eight different solution strategies including cross product algorithm, factor of change, building up, equivalent fractions unit rate, part-to-part reasoning, ratio tables and part-to-whole reasoning. The number of strategies used in each problem ranged between two and five. As a whole, the most frequent strategies used by the students were cross product algorithm, factor of change strategy and part-to-part reasoning strategy. However, cross product algorithm was the most frequent strategy among all strategies. This strategy has no physical referent and lacks meaning for students. Therefore, cross product algorithm should not be introduced to students until they have many experiences with intuitive and conceptual strategies such as factor of change strategy, build-up strategy or unit rate strategy.

Keywords:

Proportional reasoning, seventh grade students, solution strategies, cross product algorithm

(C) 2014 IJESIM. All rights reserved

Article History:

Received 23.07.2014 Received in revised form 28.11.2014 Accepted 29.11.2014 Available online 04.12.2014

\section{Extended Abstract}

\section{Introduction}

Lamon (2012) stated that "proportional reasoning is reasoning up and down in situations in which there exists an invariant (constant) relationship between two quantities that are linked and varying together.

As the word reasoning implies, it requires argumentation and explanation beyond the use of symbols $\frac{a}{b}=\frac{c}{d}$ "

(p. 3). Proportional reasoning plays a watershed role at the borderline since it is both a cornerstone of algebra and other higher level areas of mathematics and a capstone of elementary arithmetic, number, and measurement concepts (Post, Behr \& Lesh, 1988). Nevertheless, proportional reasoning requires mathematical thinking that is especially difficult for children (Fujmura, 2001). Similarly, Lamon (2007)

${ }^{1}$ Corresponding author's address:Department of Elementary Education, Faculty of Education, Aksaray University, Aksaray, TURKEY, 68100

Telephone: +(90) 3822802233

Fax:+(90) 3822802226

e-mail:ramazan.avcu@metu.edu.tr

http://dx.doi.org/10.17278/ijesim.2014.02.003 
expressed that "of all the topics in the school curriculum, fractions, ratios, and proportions arguably hold the distinction of being the most protracted in terms of development, the most difficult to teach, the most mathematically complex, the most cognitively challenging, the most essential to success in higher mathematics and science, and one of the most compelling research sites" (p. 629). Hines and McMahon (2005) reported that "proportional reasoning is based on the variety of interpretations and strategies shown by students as they reason about proportional relationships" (p. 89). Thus, it is possible to learn about students' proportional reasoning skills by investigating the strategies used by them while solving proportion problems. In mathematics education literature, there is a large body of research related with learners' proportional reasoning strategies (e.g., Bart, Post, Behr, \& Lesh, 1994; Ben-Chaim, Fey, Fitzgerald, Benedetto, \& Miller, 1998). However, few studies have been conducted in Turkey that focus on learners' use of proportional reasoning strategies (e.g., Akkuş-Çıkla\&Duatepe, 2002; Duatepe, Akkuş-Çıkla\&Kayhan 2005). Thus, the current study attempted to fill this gap by examining seventh grade students' proportional reasoning strategies. In this sense, the investigated research question was: What are the strategies used by seventh grade students while solving proportional reasoning problems?

\section{Method}

The current study used survey methodology to describe seventh grade students' proportional reasoning strategies. The sample of the study comprised of three different middle schools of a city located in the inner region of Turkey. Convenience sampling and cluster random sampling were used to select the sample of this study. In total, 278 students (157 boys and 121 girls) took part in the study. Proportional Reasoning Test (PRT) was developed by the researchers and it was based upon problems discussed in the relevant literature. PRT consisted of five open ended problems and it was developed in parallel with the objectives of revised elementary mathematics curriculum (MEB, 2009).Descriptive analysis of quantitative data primarily consisted of frequencies and percentages. Each problem was graded by using a rubric. Interrater reliability was calculated to measure the internal consistency of the PRT. Hopkins (1998) suggested that "the relevant type of validity in the measurement of academic achievement is content validity" ( $p .72$ ). Therefore, two mathematics educators working at an education faculty examined the problems to establish the content validity of the PRT. Finally, the correct solution strategies used by the students were coded by considering pre-existing proportional reasoning strategies in the mathematics education literature.

\section{Findings}

The results of this study were reported based on students' correct proportional reasoning strategies. Analysis of students' correct responses showed eight different solution strategies including cross product algorithm, factor of change, building up, equivalent fractions unit rate, part-to-part reasoning, ratio tables and part-to-whole reasoning. The number of strategies used in each problem ranged between two and five. For instance, students used five different strategies for the fuel problem while they used two different strategies for the flag problem. In addition, the strategies used to solve a problem differed from those that were used to solve another problem. To give an example, students used cross product algorithm, factor of change and equivalent fractions strategies to solve the rectangle problem while they used cross product algorithm, part-to-part, and part-to-whole strategies for the mixture problem.

As a whole, some strategies were used more frequently by students than other strategies. For example, in three out of five problems students used cross product algorithm. Thus, this was the most frequent strategy used by students when solving PRT. More specifically, over than three-fourths of the students used cross product algorithm when solving flag and rectangle problems. Similarly, about half of the students used this algorithm to solve the fuel problem. Another frequent strategy used by students was part-to-part reasoning. Roughly, ninety percent of the students preferred this strategy when solving the mixture problem. However, this strategy was not used while solving the remaining four problems. Besides, sevententh of the students used factor of change strategy to solve the popcorn problem. This strategy was also used to some extent while solving other problems except for the mixture problem.

The results showed that students used the following strategies less frequently: ratio table, part-towhole strategy and equivalent fractions strategy. These strategies were used only in one or two problems. Ratio tables, equivalent fractions and par-to-part reasoning strategies were used to solve fuel problem, 
rectangle problem, and mixture problem respectively. In addition, build-up and unit rate strategies were used while solving both fuel and popcorn problems.

\section{Discussion}

In this study, seventh grade students used eight different proportional reasoning strategies. The most frequent strategies were cross product algorithm, factor of change strategy and part-to-part reasoning strategy. On the other hand, ratio tables, build-up strategy, unit rate strategy and part-to-part reasoning strategy were less frequently used by the students. However, cross product algorithm was the most frequent strategy among all strategies. This strategy has no physical referent and lacks meaning for students. Therefore, cross product algorithm should not be introduced to students until they have many experiences with intuitive and conceptual strategies such as factor of change strategy, build-up strategy or unit rate strategy. In addition, to have students learn such conceptual strategies, teachers should know a wide range of strategies and should be able to use them during classroom practices. Besides, seventh grade students' awareness of proportional reasoning strategies can be enhanced by providing them with textbooks that are rich in tasks requiring a variety of solution strategies. Therefore, textbook authors are expected to share the responsibility in having students adopt a wide range of proportional reasoning strategies. 


\title{
Yedinci Sınıf Öğrencileri Orantısal Akıl Yürütme Gerektiren Problemlerin Çözümünde Hangi Stratejileri Kullanıyorlar?
}

\author{
Ramazan Avcu1, Mustafa Doğan² \\ ${ }^{1}$ Aksaray Üniversitesi, Eğitim Fakültesi, İlköğretim Bölümü Matematik Eğitimi Ana Bilim Dalı, Aksaray, TURKEY \\ ${ }^{2} Y$ ıldız Teknik Üniversitesi, Ĕ̆itim Fakültesi, İlköğretim Bölümü Matematik Eğitimi Ana Bilim Dall, İstanbul, TURKEY
}

ÖZ

\begin{abstract}
$\mathrm{Bu}$ çalışmanın amacı yedinci sınıf öğrencilerinin orantısal akıl yürütme gerektiren problemlerin çözümünde kullandıkları stratejileri incelemektir. Çalışma İç Anadolu Bölgesindeki bir il merkezinde bulunan iki devlet okulunda ve bir özel okulda yürütülmüş̧ür. Çalışmaya 163'ü erkek, 125'i kız, toplam 288 öğrenci katılmıştır. Araştırma, betimseltarama tasarımındadır. Öğrencilerin çözüm stratejilerini belirlemek amacıyla açık uçlu beş problemden oluşan Orantısal Akıl Yürütme Testi (OAYT) geliştirilmiştir. Bu problemlere verilen cevaplar dereceli puanlama anahtarı ile puanlanmıştır. Ayrıca öğrencilerin tam puan aldıkları problemlerde kullandıkları stratejiler alan yazındaki orantısal akıl yürütme stratejilerinin tanımları yardımı ile kodlanmıştır. Araştırmanın sonuçları yedinci sınıf öğrencilerinin OAYT' de yer alan problemlerin çözümünde sekiz farklı strateji kullandıklarını göstermiştir. Bu stratejiler içler dışlar çarpımı algoritması, değişim çarpanı stratejisi, parça-parça stratejisi, oran tablosu, artırma stratejisi, denk kesir stratejisi, birim oran stratejisi ve parça-bütün stratejisi olarak belirlenmiştir. Problemlerin çözümünde kullanılan stratejiler birbirinden farklılık göstermiş ve her birinde kullanılan farklı strateji sayıları iki ile beş arasında değişmiştir. Tüm problemlere verilen cevaplar dikkate alındığında öğrenciler tarafından en yaygın olarak kullanılan stratejilerin içler dışlar çarpımı algoritması ve değişim çarpanı stratejisi olduğu görülmüştür. Buna ek olarak, içler dışlar çarpımı algoritması beş problemin üçünde en sık kullanılan strateji olmuştur. Bu strateji öğrenciler tarafından ezbere kullanılan bir çözüm yolu olduğu için araştırmacılar bu stratejinin ancak birim oran, değişim çarpanı, artırma ve denk kesir stratejileri gibi sezgisel veya kavramsal stratejilerle yeterince deneyim kazanıldıktan sonra öğretilmesi gerektiğini önermiştir.
\end{abstract}

Anahtar Kelimeler:

Orantısal akıl yürütme, yedinci sınıf öğrencileri, çözüm stratejileri, içler dışlar çarpımı algoritması

(C) 2014 IJESIM. Tüm hakları saklıdır.

\section{Giriş}

Akıl yürütme bütün etmenleri dikkate alarak düşünüp akılcı bir sonuca ulaşma sürecidir (Umay, 2003). İlköğretim matematik dersi 6-8. sınıflar öğretim programı öğrencilerin akıl yürütme becerilerinin gelişimine önem vermekte ve öğrencilerin "öğrenme sürecinde akıl yürütmeyi kullanmaları; yaşantılarında, diğer derslerde ve matematikte akıl yürütme becerisini kullanmaları; akıl yürütmede öz güven duymaları; akıl yürütme ile ilgili olumlu duygu ve düşüncelere sahip olmaları" beklenmektedir (Milli Eğitim Bakanlığı, 2009, s. 17). Amerikan Ulusal Matematik Öğretmenleri Konseyi [NCTM] (2000) akıl yürütmenin öğrencilerin matematiği anlayabilmeleri için esas olduğunu vurgulamıştır. Matematikteki tüm kuralların ve işlemlerin temelinde akıl yürütme vardır. Bir konuda akıl yürütebilen biri "yeterli düzeyde bilgi sahibidir; yeni karşılaştığı durumu tüm boyutlarıyla inceler, keşfeder, mantıklı tahminlerde, varsayımlarda bulunur; düşüncelerini gerekçelendirir, bazı sonuçlara ulaşır, ulaştığı sonucu açıklayabilir ve savunabilir" (Umay, 2003, s. 235). Matematiksel akıl yürütme, matematiksel bir bilgi ağının üzerinde hem ilerler hem de yapılanır. Matematiği çok ilişkili fikirlerin bir ağı olarak görme hem akıl yürütme vurgusunun bir sonucu, hem de daha ileri bir akıl yürütme için bir temeldir (Umay ve Kaf, 2005).

Orantısal akıl yürütme, matematiksel akıl yürütmenin bir türüdür (Lesh, Post ve Behr, 1988) ve matematiği anlamada önemli bir yere sahiptir (Umay ve Kaf, 2005). Orantısal akıl yürütmeyi Flowers (1998) orantıyı kullanabilme ve anlama yeteneği olarak tanımlarken Cramer ve Post (1993), Clark ve Lesh (2003),

Sorumlu yazarın adresi: Aksaray Üniversitesi, Eğitim Fakültesi, İlköğretim Bölümü, Matematik Eğitimi Ana Bilim Dalı

Telefon: $+(90) 3822802233$

Faks:+(90) 3822802226

e-posta: ramazan.avcu@metu.edu.tr

http://dx.doi.org/10.17278/ijesim.2014.02.003 
Cramer, Post ve Currier (1993), bir orantı tarafından matematiksel olarak şekillendirilen bir durumu tanıyabilme, bu durumu sembolik olarak ifade edebilme ve orantı problemlerini çözebilme yeteneği olarak tanımlamıştır. Lamon'a (2012) göre orantısal akıl yürütme $\frac{a}{b}=\frac{c}{d}$ sembollerini kullanabilmenin ötesinde tartışma ve açılama gerektirir. Orantısal akıl yürütme, keşfetme, ifade etme, analiz etme, orantısal ilişkilerle ilgili iddialara delil sağlamayı da gerektirir. Boyer, Levine ve Huttenlocher (2008) oran-orantı aracılığıyla akıl yürütmede rasyonel büyüklükler arasındaki çarpımsal ilişkiyi anlamanın gerekliliğini dile getirmişlerdir. Orantısal akıl yürütme, matematiğin somut ve sayısal olan aritmetik alanıyla cebir ve ileri matematikteki soyutlamalar arasında önemli bir köprü vazifesi üstlenir (Fuson ve Abrahamson, 2005; Lamon, 2007; Post, Behr ve Lesh, 1988). Matematik eğitimcileri orantısal akıl yürütme becerisini ilköğretim matematiğinin köşe taşı olarak nitelendirmişlerdir (National Research Council, 2001). Buna rağmen, orantısal akıl yürütme ilköğretim öğrencilerine oldukça zor gelmektedir (Fujmura, 2001). Orantısal bir durumda gerçekten ne anlatılmak isteniyor ya da verilen bir strateji neden işe yarıor gibi sorulara yanit veremeyen çocukların orantısal akıl yürütmede güçlük çektiği görülmüştür (Cramer ve Post, 1993; Lesh vd., 1988).

Oran-orantı konularına hem ilköğretim matematik programında hem de ortaöğretim matematik programında yer verilmiştir. Bu konular önemli bir akıl yürütme becerisi içermesi ve birçok matematiksel kavramın anlaşılması için gerekli olması nedeniyle, ilköğretim ve ortaöğretim matematiğinde oldukça önemli bir yere sahiptir (Akkuş ve Duatepe-Paksu, 2006). NCTM (2000) orantısal akıl yürütmeyi, öğrencilerin iş ve günlük hayatlarında kullanabilecekleri bir akıl yürütme biçimi olarak belirtilmiştir. Bu konuda akla gelen ilk örnek, fiyatların karşılaştırıldığı bir günlük alışveriş durumu olabilir. Oran-orantı, gündelik hayatta karşılaşılan problemlerin çözümünde, ileri matematik konularının öğrenilmesinde ve fizik, kimya gibi bilim dallarında oldukça sık kullanıldığı için bu kavramlar diğer bilim dalları için merkezi bir rol üstlenmektedirler (Post vd., 1988). Sowder vd. (1998) öğrencilerin kesirler, ondalık sayılar, orantı, yüzde gibi kavramları anlamlandırabilmeleri için gerekli olan çarpımsal ilişkiyi temel alan orantısal akıl yürütme becerisinin vazgeçilmez olduğunu belirtmiş, Lesh vd.(1988) ise orantısal akıl yürütmenin öğrencilerin ilkokul aritmetik bilgilerini daha ileri sınıflardaki matematik konularına bağlayacak temel bir konu olduğu üzerinde durmuşlardır. Vergnaud'un (1983) da ifade ettiği gibi oran-orantı matematiksel kavramları öğrenmede merkezi olarak kabul edilir, çünkü oran-orantı çarpma, bölme, kesirler ve doğrusal fonksiyonlar gibi kavramlarla ilişkilidir.

Öğrencilerin orantısal akıl yürütme düzeyleri verilen orantısal duruma yönelik yorumlarının ya da kullandıkları stratejilerin çeşitliliği göz önünde bulunarak belirlenmektedir (Hines ve McMahon, 2005). Matematik eğitiminde öğrencilerin orantısal akıl yürütme gerektiren problemlerde kullandıkları çözüm stratejileri ile ilgili uluslararası alanda yapılmış birçok çalışma bulunmaktadır (Bart, Post, Behr ve Lesh, 1994;Ben-Chaim, Fitzgerald, Benedetto ve Miller, 1998; Cramer ve Post, 1993; Cramer vd., 1993; LevinWeinberg, 2002; Parker, 1999; Singh, 2000). Buna rağmen ulusal alan yazında orantısal akıl yürütme stratejileri ile ilgili olarak çok az sayıda çalışma yapılmıştır (Akkuş-Çıkla ve Duatepe, 2002; Duatepe, AkkuşÇıkla ve Kayhan, 2005; Kayhan, 2005). Ulusal alan yazındaki bu boşluğu gidermek amacıyla bu çalışmada 7. sınıf öğrencilerinin orantısal akıl yürütme gerektiren problemlerin çözümünde kullanmış oldukları stratejileri belirlemeye odaklanılmıştır. Bu doğrultuda araştırmada şu soruya yanıt aranmıştır: Yedinci sınıf öğrencilerinin orantısal akıl yürütme gerektiren problemlerin çözümünde kullandıkları stratejiler nelerdir?

\section{Orantısal Akıl Yürütme Stratejileri}

Bart vd. (1994) orantısal akıl yürütme gerektiren problemlerin tanılayıcı analizinin yapılması, öğrencilerin bilişsel süreçlerinin ve hatalarının belirlenip ortaya çıarılması için bir bilişsel mikro-teori önermişlerdir. RNP (Rasyonel Sayı Projesi) kapsamında yapılan araştırmalarda bu mikro-teorilere dayalı çözüm stratejileri geliştirilmiş ve öğrencilerin beş farklı doğru çözüm stratejisi kullandığı belirlenmiştir. Bu stratejiler: birim oran stratejisi, değişim çarpanı stratejisi, içler-dışlar çarpımı stratejisi, denk kesir stratejisi ve denklik sınıfı stratejileridir (Cramer ve Post, 1993; Cramer vd., 1993; Bart vd., 1994). Ben-Chaimvd. (1998) ve Parker (1999) tarafından yapılan araştırmalar da ise, yukarıda bahsedilen çözüm stratejilerine ek olarak, artırma stratejisi belirlenmiş̧ir. Bu stratejilere ait tanımlar “Bir kitapçıda 4 kalem 8 TL'ye satıldığına göre 16 kalemin fiyatı toplam kaç TL olur?" problemi yardımıyla aşağıda sunulmuştur. 
İçler dışlar çarpımı algoritması stratejisi bir orantı kurmayı, daha sonra çapraz çarpım ve bölme işlemi yaparak bilinmeyen değere ulaşmayı içerir. Diğer bir ifadeyle;

4 kitap $8 \mathrm{TL}$

16 kitap $x$ TL

$x=(16 \times 8) / 4=32$ TL bulunur.

Ya da şu şekilde de çözüme gidilebilir. Bu problemde orantı $\frac{4 \text { adet }}{8 \mathrm{TL}}=\frac{16 \text { adet }}{x}$ şeklinde oluşturulur ve $x=16$ adet $\times \frac{8 \text { TL }}{4 \text { adet }}=32$ TL bulunur (Bart vd., 1994; Cramer ve Post, 1993; Cramer vd., 1993).

Denk kesir stratejisinde oran çiftleri kesir olarak ele alınır. Burada amaç verilen kesre denk bir kesir bulmaktır. Bunun için kesir $\frac{n}{n}$ şeklinde 1'e eşit bir kesirle çarpılır ve çarpılan oranın bir terimi diğer oranın aynı terimine eşit olur. Bu problemde $\frac{4}{8} \equiv \frac{16}{x}$ yazılır ve $\frac{4}{8}$ kesri $\frac{4}{4}$ kesri ile çarpılarak yine bu kesre denk $\frac{16}{32}$ kesri elde edilir. Buradan $x=32$ TL bulunur (Bart vd., 1994).

Denklik sınıfı stratejisi verilen oran çiftini kesir olarak ele almayla ilgilidir. Öğrenci sonradan istediği oranı buluncaya kadar belirlediği kesre denk kesirler sınıfı oluşturur. Bu problemde $\frac{4 \text { adet }}{8 \mathrm{TL}}$ oranı $\frac{4}{8}$ kesri ile belirlenir ve bu kesre denk kesirler sınıfı $\frac{4}{8} \equiv \frac{8}{16} \equiv \frac{16}{32}$ oluşturulur $\frac{16}{32}$ kesri ile belirlenen oran $\frac{16 \text { adet }}{32 \mathrm{TL}}$ olacağından bu orandan $x=32$ TL bulunur (Bart vd., 1994).

Değişim çarpanı stratejisi her bir kişinin aldığı kalem adedini karşılaştırmayı; bir kişinin aldığı adet ile diğerinin aldığı adet arasında değişim çarpanı belirlemeyi ve birinci kişinin ödediği meblağ ile değişim çarpanını çarpma işlemine tabi tutmayı içerir. Bu problemde Veli, Ali'nin aldığı kalem sayısının 4 katı kadar almıştır $(16: 4=4)$ ve Veli Alinin ödediği meblağın 4 katını ödemelidir ( $4 \times 8 \mathrm{TL}=32 \mathrm{TL})$ (Bart vd., 1994; Cramer ve Post, 1993; Cramer vd., 1993).

Artırma stratejisi problemde verilen bir oranla başlamayı ve istenen oran elde edilinceye kadar eşit oranlar oluşturmayı içerir. Bu strateji "liste yapmak" ve "örüntüyü yakalamak" olarak da adlandırılabilir (Ben-Chaimvd., 1998; Parker, 1999 ). Verilen problem artırma stratejisi kullanılarak aşağıdaki gibi çözülebilir.

4 kalem 8 TL

8 kalem 16 TL

16 kalem 32 TL

Daha anlaşılır olması açısından bu stratejiye bir örnek daha verilecek olursa "600 kilometre yolu 4 saatte alan bir otomobil, aynı hızda giderse 1500 kilometrelik bir yolu kaç saatte alır? " problemi artırma stratejisi yardımıyla şu şekilde çözülebilir:

$600 \mathrm{~km} 4$ saatte

$300 \mathrm{~km} 2$ saatte

$1200 \mathrm{~km} 8$ saatte

$1500 \mathrm{~km}=1200 \mathrm{~km}+300 \mathrm{~km}$ buradan 8 saat +2 saat $=10$ saatte alır.

Birim oran stratejisi bir kalemin fiyatının hesaplanmasını ve sonra bu birim fiyatın istenen cevabı bulmak için satın alınan kalem adedi ile çarpımın içerir. Bu cevap Veli'nin ödemesi gereken meblağdır. Bu problemde bir kalemin fiyatı 2 TL'dir $(8 \mathrm{TL}: 4=2 \mathrm{TL})$. Bu nedenle 16 kalem $32 \mathrm{TL}$ olur $(2 \mathrm{TL} \times 16=32 \mathrm{TL})$ (Bart vd., 1994; Cramer ve Post, 1993; Cramer vd., 1993).

\section{Yöntem}

\section{Araștırmanın Deseni}


Araştırma, 7. sınıf öğrencilerinin orantısal akıl yürütme becerileriyle ilgili olarak var olan durumları saptamayı amaçladığı için betimsel-tarama modelindedir. Tarama araştırmaları bir konuya ya da olaya ilişkin katılımcıların görüşlerinin ya da ilgi, beceri, yetenek, tutum vb. özelliklerinin belirlendiği genellikle diğer araştırmalara göre daha büyük örneklemler üzerinde yapılan araştırmalardır (Büyüköztürk, Çakmak, Akgün, Karadeniz ve Demirel, 2009).

\section{Araştırmanın Örneklemi}

Araştırmanın örneklemini İç Anadolu Bölgesinde bulunan bir ildeki iki devlet okulu ve bir özel okulda öğrenim görmekte olan 7. sınıf öğrencileri oluşturmaktadır. Okullara ulaşımın kolay olması için araştırmanın katılımcları uygun örnekleme yoluyla seçilmiştir. Ayrıca, basit tesadüfî örnekleme yoluyla veya tabaka örnekleme yoluyla yapılan örneklem seçiminde uygulama izni almak ve veri toplamak küme örnekleme yöntemine göre daha zor ve zaman alıcı olduğundan (Judd, Smith ve Kidder, 1991) bu çalışmada küme örnekleme yöntemi tercih edilerek birinci devlet okulundan 4 sınıf, ikinci devlet okulundan 2 sınıf ve özel okuldan 4 sınıf çalışma kapsamına alınmıştır. Araştırmaya katılan öğrencilerin okullara göre dağılımı Tablo 1'de gösterilmiştir.

Tablo 1. Yedinci sınıf öğrencilerinin okul ve cinsiyete göre dağılımı

\begin{tabular}{lcccccc}
\hline \multicolumn{1}{c}{ Okul } & \multicolumn{3}{c}{ Cinsiyet } \\
\cline { 2 - 8 } & \multicolumn{2}{c}{ Erkek } & \multicolumn{2}{c}{ Kiz } & \multicolumn{2}{c}{ Toplam } \\
\cline { 2 - 8 } Devlet Okulu-1 & $\mathrm{f}$ & $\%$ & $\mathrm{f}$ & $\%$ & $\mathrm{f}$ & $\%$ \\
\cline { 2 - 8 } Devlet Okulu-2 & 80 & 27,78 & 58 & 20,14 & 138 & 47,92 \\
Özel Okul & 26 & 9,03 & 29 & 10,07 & 55 & 19,10 \\
\hline Genel Toplam & 57 & 19,79 & 38 & 13,19 & 95 & 32,99 \\
\hline
\end{tabular}

Tabloda görüldüğ̈̈ gibi oran-orantı başarı testinin uygulandığı toplam öğrenci sayısı 288'dir. Öğrencilerin 163'ü erkek (\%56,60), 125'i (\%43,40) kızdır.

\section{Veri Toplama Aracı}

Veri toplama aracı 6. ve 7. sınıflar için uygulamada olan İlköğretim Matematik Dersi Öğretim Programının (MEB, 2009) sayılar öğrenme alanı, oran-orantı alt öğrenme alanına ait kazanımları dikkate alınarak geliştirilen Orantısal Akıl Yürütme Testi (OAYT) kullanılmıştır. Bu kazanımlar programda şu şekilde belirtilmiştir: "Nicelikleri karşılaştırmada oran kullanır ve oranı farklı biçimlerde gösterir; orantıyı ve doğru orantılı nicelikler arasındaki ilişkiyi açıklar; doğru orantılı ve ters orantılı nicelikler arasındaki ilişkiyi açıklar; doğru ve ters orantıyla ilgili problemleri çözer ve kurar" (MEB, 2009, s. 119, s. 214). OAYT'deki problemler ilgili alan yazında tartışlan problemlerden ve okullarda okutulmakta olan matematik ders ve çalışma kitaplarındaki oran-orantı problemlerinden seçilmiştir. OAYT'deki problemler ve problemlerin kaynakçaları Tablo 2'de belirtilmiştir.

Öğrencilerin orantısal akıl yürütme becerisini değerlendirmede bilinmeyen değer problemleri, sayısal karşılaştırma problemleri ve niteliksel tahmin ve karşılaştırma problemleri şeklinde üç farklı problem türü bulunmaktadır (Cramer vd., 1993). OAYT'de bulunan yakıt problemi ve bayrak problemi bilinmeyen değeri bulma türünde problemler olup patlamış mısır problemi, dikdörtgen problemi ve karışım problemi sayısal karşılaştırma türünde problemlerdir.

Yakıt problemi 7. Sınıf matematik ders kitabında "Bir otomobil 480 km'de 30 litre benzin yakıyor. 182 km'de 12 litre benzin yakar" şeklinde ifade edilmiştir. Bu problemde küçük sayılar kullanmanın öğrencilerin orantısal akıl yürütme becerilerini daha iyi ortaya koyacağı düşünüldüğü için problem yukarıdaki haline uyarlanmıştır. Ayrıca problemin orijinalinde 4 sayısal değer de belirtildiği için sayısal karşılaştırma türünde bir problem iken uyarlanmış problemde 3 sayısal değer verilip sonuncunun bulunması istendiği için bilinmeyen değer türünde bir probleme dönüşmüştür. 
Tablo 2. Orantısal akıl yürütme testindeki problemler

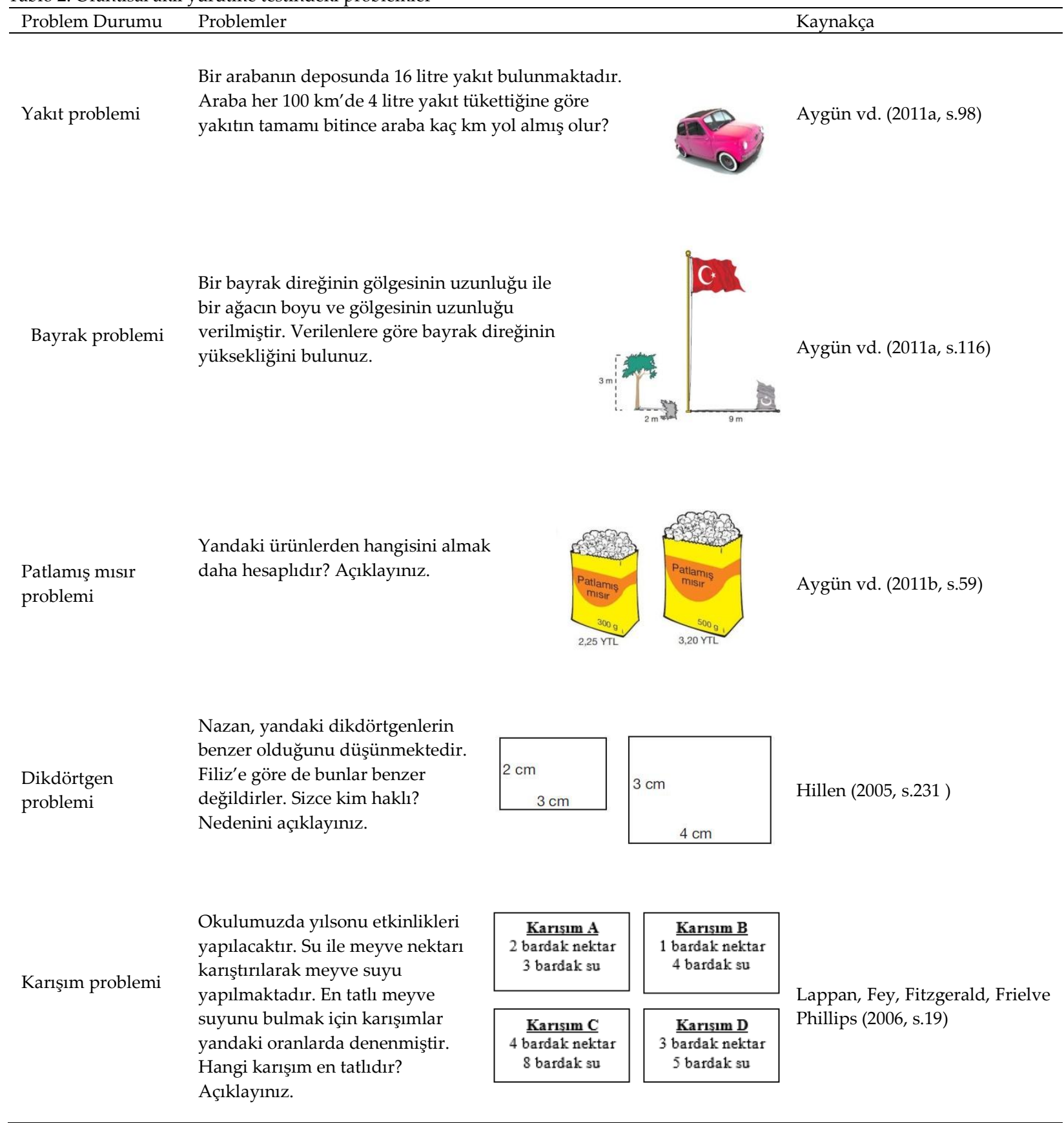

Bayrak probleminin içeriğinde herhangi bir değişikliğe gidilmemiş, 7. sınıf matematik ders kitabında ifade edildiği haliyle OAYT'ye dâhil edilmiştir. Bu problemin yakıt probleminden farkı sayısal değerler arasında tam kat ilişkisinin olmamasıdır. Daha açık bir ifadeyle, yakıt probleminde yakıt miktarları arasında tam kat bir ilişki söz konusu iken bu problemde bayrak direği ile gölgesi arasında tam kat bir ilişki bulunmamaktadır.

Patlamış mısır problemi "karlı alışveriş" problemlerine örnek olarak gösterilebilir (Lamon, 2012, s. 106). Bu problem 7. sınıf matematik çalışma kitabından içeriğinde herhangi bir değişikliğe gidilmeden OAYT'ye dâhil edilmiştir. Patlamış mısırların fiyatları ondalık sayı biçiminde verildiği için mısırların birer gramını bulmak öğrenciler için zor olacağından fiyat karşılaştırması yaparken öğrencilerden farklı stratejiler geliştirmeleri beklenmektedir.

Dikdörtgen problemi Hilen (2005)'in araştırmasında bilinmeyen değeri bulma türünde ifade edilmiştir. Bu problemin niceliksel karşılaştırma problemi olarak uyarlanmasında öğrencilerin düşünme 
süreçlerinin toplamsal akıl yürütmeden çarpımsal akıl yürütmeye geçip geçmediğini daha kolay ortaya koyma düşüncesi etkili olmuştur. Daha net bir ifadeyle, her iki dikdörtgenin uzun kenar-kısa kenar uzunlukları farkı $1 \mathrm{~cm}$ olduğundan toplamsal akıl yürütme düzeyinde olan öğrencilerin bu dikdörtgenlerin benzer olacağını belirtmeleri beklenmektedir.

Lappan vd. (2006) tarafından geliştirilen karışım probleminin sayısal değerlerinde ve sözel ifadelerinde değişikliğe gidilerek yukarıdaki karışım problemi elde edilmiştir. Bu problem sayısal karşılaştırma türünde olup OAYT'deki diğer sayısal karşılaştırma problemlerinden farklı olarak öğrencilerden dört oranı karşılaştırmaları beklenmektedir.

\section{Ölçme aracının güvenirliği ve geçerliği}

OAYT'nin güvenilirliğini incelemek için tek uygulamaya dayalı yöntemlerden Cronbach Alpha $(\alpha)$ iç tutarlılık katsayısı hesaplanmıştır. (Creswell, 2012). Büyüköztürk ve diğerlerine göre (2009) " $\alpha$ katsayısı özellikle cevapların derecelendirme ölçeğinde elde edildiği durumlardan sıklıkla kullanılmaktadır" (s. 110111). OAYT'nin Cronbach Alpha iç güvenirlik katsayısı 0, 69 olarak bulunmuştur. Bir ölçme aracının Cronbach Alpha katsayısı tercihen 0,70 ve üzerinde olmalıdır (DeVellis, 2003). İç güvenirlik katsayısının 0,70'den az da olsa düşük çıkmasında OAYT'nin yalnızca 5 problemden oluşmasından kaynaklandığı düşünülmektedir. Bununla ilgili olarak Pallant (2007) Cronbach Alpha katsayısının ölçme aracındaki madde sayısına çok duyarlı olduğunu ve madde sayısının az olduğu durumlarda Cronbach Alpha değerlerinin oldukça düşük çıkabileceğini (örneğin 0,50 gibi) belirtmiştir. Buradan hareketle araştırmacılar OAYT'nin güvenirliğinin yeterli düzeyde olduğuna karar vermişlerdir.

Geçerlik, bir ölçme aracının ölçülmek istenen özelliği diğer özelliklerle karıştırmadan ne derece doğru ölçtüğü ile ilgilidir (Büyüköztürk vd, 2009). Crocker ve Algina (2006) geçerlik türlerini kapsam, ölçüt ve yap1 geçerliği olmak üzere üç grupta toplamıştır. Hopkins'e (1998) göre "akademik başarının ölçüldüğü testlerde kullanılan geçerlik yöntemi kapsam geçerliğidir" (p. 72). Bu çalışmada geliştirilmekte olan OAYT bir tür başarı testi olduğu için kapsam geçerliği üzerinde durulacaktır. Kapsam geçerliğini sağlamak için araştırmacılar OAYT' de bulunan problemler farklı stratejiler kullanılarak çözülebiliyor mu? sorusuna cevap aramaya çalışmışlardır. Bu amaçla problem-çözüm stratejisi karşlaştırmasını içeren bir belirtke tablosu hazırlanmıştır. Bu tabloda aşağıda verilmiştir.

Tablo 3. Belirtke tablosu

\begin{tabular}{|c|c|c|c|c|c|}
\hline \multirow{2}{*}{ Orantısal Akıl Yürütme Stratejileri (OAYS) } & \multicolumn{5}{|c|}{ OAYT' deki problemler } \\
\hline & Yakit & Bayrak & Patlamış mısır & Dikdörtgen & Karışım \\
\hline İçler dışlar çarpımı algoritması & $\mathrm{x}$ & $\mathrm{x}$ & $\mathrm{x}$ & $\mathrm{x}$ & $\mathrm{x}$ \\
\hline Değişim çarpanı & $x$ & $x$ & $\mathrm{x}$ & $x$ & $x$ \\
\hline Artırma stratejisi & $x$ & $x$ & $x$ & $x$ & $\mathrm{x}$ \\
\hline Denk kesir & $\mathrm{x}$ & $\mathrm{x}$ & $\mathrm{x}$ & $\mathrm{x}$ & $\mathrm{x}$ \\
\hline Birim oran & $\mathrm{x}$ & $\mathrm{x}$ & $\mathrm{x}$ & $\mathrm{x}$ & $\mathrm{x}$ \\
\hline Oran tablosu & $\mathrm{x}$ & $\mathrm{x}$ & $x$ & $\mathrm{x}$ & $x$ \\
\hline Parça-parça stratejisi & & & & & $\mathrm{x}$ \\
\hline Parça-bütün stratejisi & & & & & $\mathrm{x}$ \\
\hline Toplam OAYS sayısı & 6 & 6 & 6 & 6 & 8 \\
\hline
\end{tabular}

Kapsam geçerliğini belirlemek için OAYT bir eğitim fakültesinde görev yapmakta olan iki matematik eğitimcisi tarafından yukarıdaki tablo göz önünde bulundurularak incelenmiştir. Matematik eğitimcileri görüşlerini dile getirmişler ve OAYT ile ilgili gerekli düzeltmeler yapılmıştır. Ayrıca, İngilizce'den Türkçe'ye uyarlanan problemler ifade ediliş biçimleri açısından Türkçe eğitiminde doktora derecesine sahip bir öğretim üyesi tarafından incelenmiş ve yanlış yorumlamalara neden olabilecek ifadeler düzeltilmiştir.

\section{Verilerin Analizi}


$\mathrm{Bu}$ araştırmada OAYT’nin her bir maddesi için Allain (2000) tarafından geliştirilen 4 dereceli puanlama yönergesi kullanılmıştır. Bu puanlama yönergesi Tablo 4'te sunulmuştur.

Tablo 4. Dereceli puanlama anahtarı

\begin{tabular}{cl}
\hline Puan & Detaylar \\
\hline \multirow{3}{*}{4} & $\begin{array}{l}\text { Kavramı anladığını gösterme } \\
\text { Problemi çözmek için uygun bir strateji kullanma } \\
\text { Doğru cevabı bulma }\end{array}$ \\
\hline \multirow{3}{*}{3} & $\begin{array}{l}\text { Kavramı anladığını gösterme } \\
\text { Problemi çözmek için uygun bir strateji kullanma } \\
\text { Olası bir matematik hatasından dolayı sonucu yanlış bulma }\end{array}$
\end{tabular}

\section{Kavramı kısmen anlama ya da kavramla ilgili kavram yanılgısına sahip olma}

2 Problemi çözerken hatalı çözüm stratejisi kullanma ya da açıklama yapmadan doğrudan cevabı yazma

Problemi eksik olarak cevaplama ya da problemin doğru cevabına tahmin yoluyla ulaşma

Kavram yanılgısına sahip olma
1 Problemi çözerken hatalı çözüm stratejisi kullanma ya da problemi boş bırakma

Problemin cevabını yanlış bulma

Allain (2000, s. 68)

$\mathrm{Bu}$ çalışmada oran-orantı problemlerinin çözümünde 7. sınıf öğrencileri tarafından kullanılan stratejiler matematik eğitimi alan yazınında yer alan orantısal akıl yürütme stratejileri yardımıyla kodlanmıştır. Ayrıca, öğrencilerin kullanmış olduğu stratejiler matematik eğitimi alanında doktora yapmakta olan başka bir araştırmacı tarafından bağımsız olarak kodlanmıştır. İki farklı araştırmacı tarafından yapılan kodlamalar birbirleriyle karşılaştırılmış ve kodlayıcılar arası uyuşmazlık birkaç oturum sonunda giderilmiştir.

Yapılan kodlamalar SPSS programına girilerek betimsel istatistik türlerinden frekans ve yüzde analizleri yapılmıştır. Bulguların raporlanmasında içler dışlar çarpımı algoritması, denk kesir stratejisi, değişim çarpanı stratejisi, artırma stratejisi ve birim oran stratejisi gibi doğru çözüm stratejileri ele alınmıştır. Duygusal cevap verme, toplamsal ilişki, veri ihmali, sayıları kullanma ve içerik yok stratejisi gibi hatalı çözüm stratejilerinin kullanıldığı ve problemin boş bırakıldığı ya da doğrudan cevabın yazıldığı durumlara odaklanılmamıştır.

\section{Bulgular}

$\mathrm{Bu}$ bölümde orantısal akıl yürütme testinden elde edilen verilere ait bulgular sunulmuştur. Öğrencilerin problem çözümünde kullandıkları stratejiler belirlenirken sadece probleme doğru cevap veren öğrencilerin çözümleri dikkate alınmıştır. Öncelikle testte kullanılan stratejiler genel olarak verilmiştir. Bu sayede kullanılan strateji çeşitliliğinin daha kolay bir şekilde görülebileceği düşünülmüştür. Sonrasında çözüm stratejileri problem bazında örneklendirilerek detaylandırılmıştır. Orantısal akıl yürütme testinde kullanılan stratejilerin problemlere göre dağılımı Tablo 5'de sunulmuştur.

Tablo 5. OAYT'de kullanılan stratejilerin frekans ve yüzde değerleri

\begin{tabular}{|c|c|c|c|c|c|}
\hline Çözüm stratejileri & Yakıt problemi & Bayrak problemi & $\begin{array}{l}\text { Patlamış misır } \\
\text { problemi }\end{array}$ & $\begin{array}{c}\text { Dikdörtgen } \\
\text { problemi }\end{array}$ & Karışım problemi \\
\hline $\begin{array}{l}\text { İçler dışlar çarpımı } \\
\text { algoritması }\end{array}$ & $74(\% 44,58)$ & $143(\% 86,14)$ & $33(\% 31,13)$ & $68(\% 80,95)$ & $5(\% 4,95)$ \\
\hline Değişim çarpanı & $57(\% 34,34)$ & $22(\% 13,25)$ & $68(\% 64,15)$ & $5(\% 5,95)$ & - \\
\hline Parça-parça & - & - & - & - & $88(\% 87,13)$ \\
\hline Oran tablosu & $17(\% 10,24)$ & - & - & - & - \\
\hline Artırma & $12(\% 7,23)$ & - & $3(\% 2,83)$ & - & - \\
\hline Denk kesirler & - & - & - & $11(\% 13,10)$ & - \\
\hline Birim oran & $6(\% 3,61)$ & - & $2(\% 1,89)$ & - & - \\
\hline Parça-bütün & - & - & - & - & $8(\% 7,92)$ \\
\hline
\end{tabular}




\begin{tabular}{llllll}
\hline Toplam & $166(\% 100)$ & $165(\% 100)$ & $106(\% 100)$ & $84(\% 100)$ & $101(\% 100)$ \\
\hline
\end{tabular}

Not:Yüzde değerleri her bir probleme verilen doğru cevap üzerinden hesaplanmıştır.

Tüm problemlere verilen cevaplar dikkate alındığında 7. sınıf öğrencilerinin sekiz farklı orantısal akıl yürütme stratejisi kullandıkları görülmüştür. Bir problemin çc̈zümünde kullanılan farklı strateji sayıları iki ile beş arasında değişmiştir. Örneğin, öğrenciler yakıt problemini beş farklı strateji kullanarak çözerken bayrak problemini iki farklı strateji ile çözmüşlerdir. Öte yandan, her bir problemde kullanılan stratejiler birbirinden farklılık göstermiştir. Örneğin, dikdörtgen probleminin çözümünde içler dışlar çarpımı algoritması, değişim çarpanı ve denk kesirler kullanılırken karışım probleminin çözümünde içler dışlar çarpımı algoritması, parça-parça ve parça bütün stratejilerini kullanmışlardır.

Veriler incelendiğinde bazı stratejilerin öğrenciler tarafından sıklıkla kullanıldığı görülmüştür. Örneğin, beş problemden üçünde en sık kullanılan stratejinin içler dışlar çarpımı algoritması olduğu görülmüştür. Özel olarak, içler dışlar çarpımı algoritmasını bayrak ve dikdörtgen problemlerinde öğrencilerin dörtte üçünden fazlası kullanmıştır. Benzer şekilde bu algoritma yakıt probleminde öğrencilerin yarıya yakını tarafından kullanılmıştır.

En sık kullanılan diğer bir strateji de parça-parça akıl yürütme stratejisidir. Bu strateji öğrencilerin yaklaşık onda dokuzu tarafından karışım probleminin çözümünde kullanılırken diğer problemlerde hiç kullanılmamıştır. Yaygın stratejilerden bir diğeri ise değişim çarpanı stratejisidir. Patlamış mısır probleminin çözümünde öğrencilerin neredeyse onda yedisi değişim çarpanı stratejisini kullanmıştır. Bu strateji karışım problemi dışında diğer problemlerde de belirli ölçüde kullanılmıştır.

Öğrencilerin oran tablosunu, artırma, denk kesir, birim oran ve parça-bütün stratejilerini daha az kullanıldığı görülmüştür. Öğrenciler bu stratejileri bir ya da iki problemin çözümünde kullanmışlarıdır. Oran tablosunu yakıt probleminin, denk kesir stratejisini dikdörtgen probleminin, parça bütün stratejisini de karışım probleminin çözümünde kullanmışlardır. Ayrıca öğrenciler artırma ve birim oran stratejilerini yakıt problemi ile patlamış mısır probleminin çözümünde kullanmışlardır.

Bundan sonraki bölümde öğrencilerin kullandıkları orantısal akıl yürütme stratejileri her bir problem için örneklendirilerek açıklanmıştır. Öğrencilerin yakıt probleminin çc̈zümünde kullandıkları stratejilere ait frekans ve yüzde değerleri ile örnek çözümleri Tablo 6'da sunulmuştur.

Tablo 6 incelendiğinde öğrencilerin yakıt probleminin çözümünde beş farklı strateji kullandığı görülmektedir. Öğrencilerin bu problemde sık kullandıkları stratejiler içler dışlar çarpımı algoritması ve değişim çarpanı stratejisi olarak belirlenmiştir. Oran tablosu, artırma ve birim oran stratejileri ise bu problemin çözümünde az da olsa kullanılan diğer stratejilerdir.

Şekil 1' de içler dışlar çarpımı algoritması örneği, biri yol uzunluğu, diğeri yakıt miktarı ile tanımlanmış iki oranın eşitliği ile oluşturulmuş orantının formülleştirilmiş hali göstermektedir. 7. sınıf öğrencilerinin kullandıkları içler dışlar çarpımı stratejisi dikkate alındığında, bu stratejinin alan yazında tanımlandığı şekliyle oluşturulduğu görülmüştür.

Şekil 2 incelendiğinde öğrencilerin öncelikle yakıt miktarlarını karşılaştırarak 4 litre ile 16 litre arasındaki değişim çarpanını 4 olarak belirlemiştir. Daha sonra bu çarpanı $100 \mathrm{~km}$ ile çarptığı görülmektedir. Sonuç olarak toplam yol 100 km'nin 4 katı yani 100 x 4=400 km olarak bulunmuştur.

Şekil 3 incelendiğinde mesafe ile yakıt miktarı arasındaki ilişki tabloya aktarılarak belirtilmiştir. Problemin sonucuna ulaşmak için başlangıçtaki yakıt miktarı (4 litre) her seferinde kendisi kadar artırılmış (4-8-12-16), buna paralel olarak başlangıçtaki yol uzunluğuna da her seferinde $100 \mathrm{~km}$ eklenmiştir (100-200300-400).

Şekil 4 incelendiğinde $100 \mathrm{~km} \div$ 4litre oranı ile başlanmış ve istenilen oran elde edilinceye kadar eşit oranlar oluşturulmuştur. Her aşamada aynı miktarda kilometre artışı ve litre artışı olmuştur. Yani yol uzunluğu $100 \mathrm{~km}-200 \mathrm{~km}-300 \mathrm{~km}$ şeklinde aradaki fark $100 \mathrm{~km}$ olacak şekilde artmış. Aynı zamanda yakıt miktarı da 4 litre-8litre-12litre-16litre şeklinde aradaki fark 4 litre olacak şekilde artmıştır. 
Şekil 5 incelendiğinde arabanın 1 litre yakıtla kaç km yol alabileceği hesaplanmış ve sonra istenen cevaba ulaşmak için birim yakıt miktarının alabileceği yol uzunluğu ile arabanın deposunda bulunan yakıt miktarı çarpılmıştır $(25 \times 16=400)$.

Tablo 6. Yakıt probleminin çözümünde kullanılan stratejiler ve örnek öğrenci çözümleri

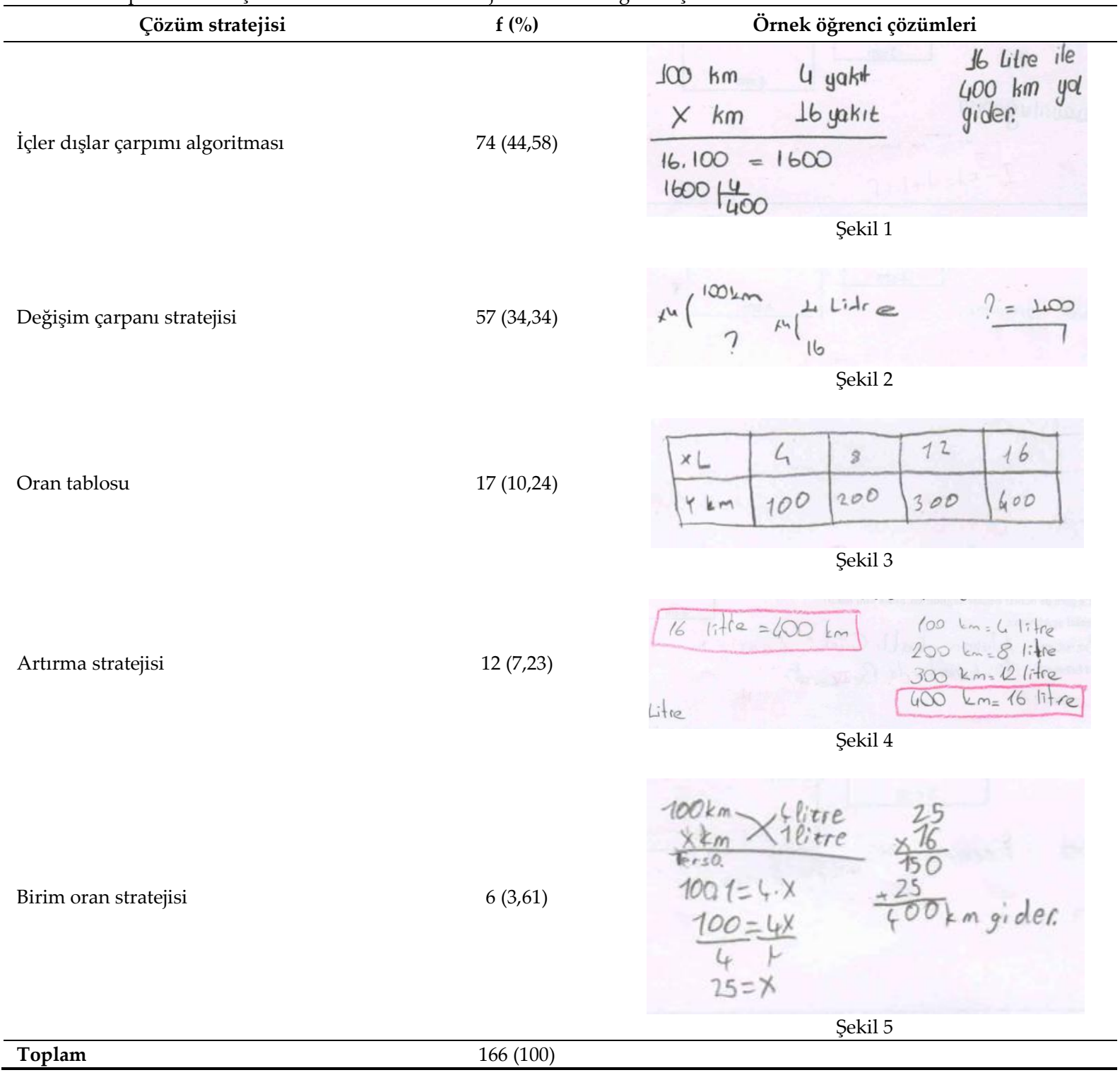

Öğrencilerin bayrak probleminin çözümünde kullandıkları stratejilere ait frekans ve yüzde değerleri ile örnek çözümleri Tablo 7'de sunulmuştur.

Tablo 7. Bayrak probleminin çözümünde kullanılan stratejiler ve örnek öğrenci çözümleri

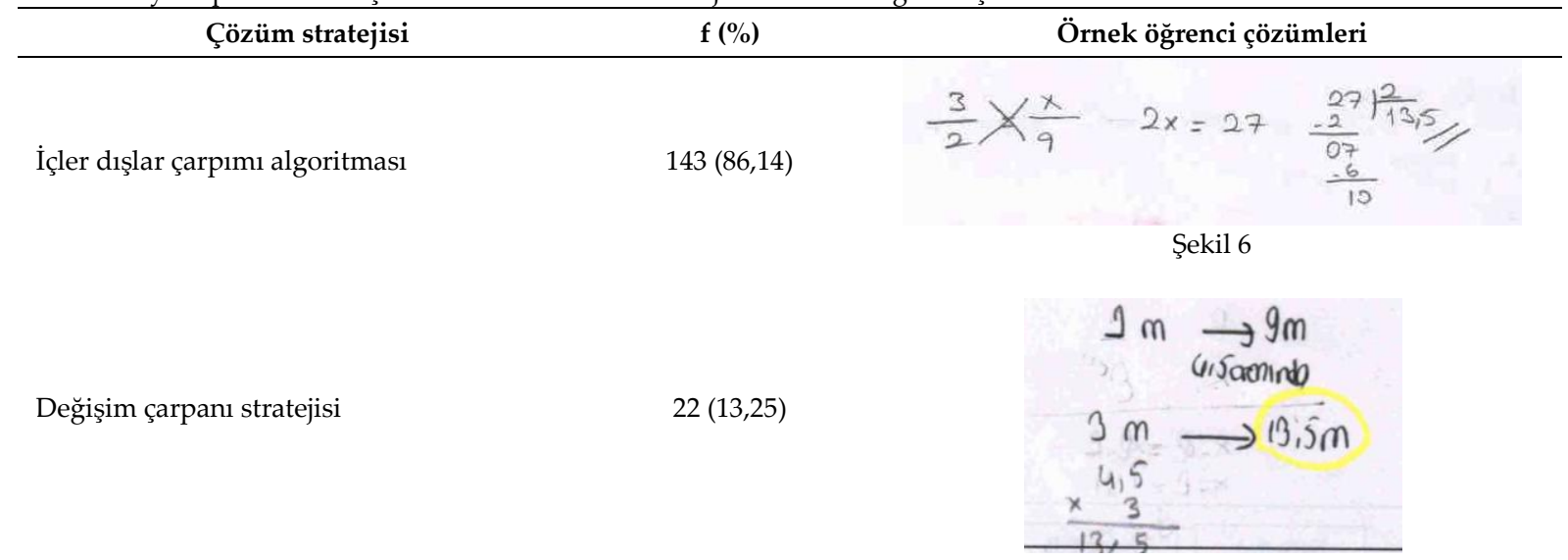




Toplam $166(100)$

Tablo 7 incelendiğinde öğrencilerin bayrak problemini çözerken iki farklı strateji kullandığ 1 görülmektedir. İçler dışlar çarpımı algoritması yakıt probleminde olduğu gibi bu problemde de öğrenciler tarafından en sık kullanılan strateji olmuştur. Öğrencilerin yaklaşık olarak \%90'ı içler dışlar çarpımı algoritmasını tercih etmişlerdir. Bu problemde kullanılan bir diğer strateji ise değişim çarpanıdır. Yakıt probleminde içler dışlar çarpımı algoritması ile değişim çarpanı stratejisinin kullanım sıklıkları birbirine yakınken bu problemde aralarında belirgin bir fark oluşmuştur.

Şekil $6^{\prime}$ da $\frac{3}{2}=\frac{x}{9}$ biçiminde bir orantı kurulmuş daha sonra çapraz çarpım yapılarak $2 x=27$ eşitliği kurulmuştur. Son olarak da bilinmeyen değer 27'nin 2'ye bölünmesiyle 13,5 olarak bulunmuştur.

Şekil 7 incelendiğinde öğrencinin ağacın gölgesi ile bayrak direğinin gölgesini karşılaştırdığı daha sonra ağacın gölgesinin uzunluğu ( 2 metre) ile bayrak direğinin gölgesinin uzunluğu (9 metre) arasındaki değişim çarpanını 4,5 olarak belirlediği ve bunu ağacın boyunun uzunluğu ( 3 metre) ile çarparak 13,5 metre bulduğu görülmektedir.

Öğrencilerin patlamış mısır probleminin çözümünde kullandıkları stratejilere ait frekans ve yüzde değerleri ile örnek çözümleri Tablo 8'de sunulmuştur.

Tablo 8. Patlamış mısır probleminin çözümünde kullanılan stratejiler ve örnek öğrenci çözümleri

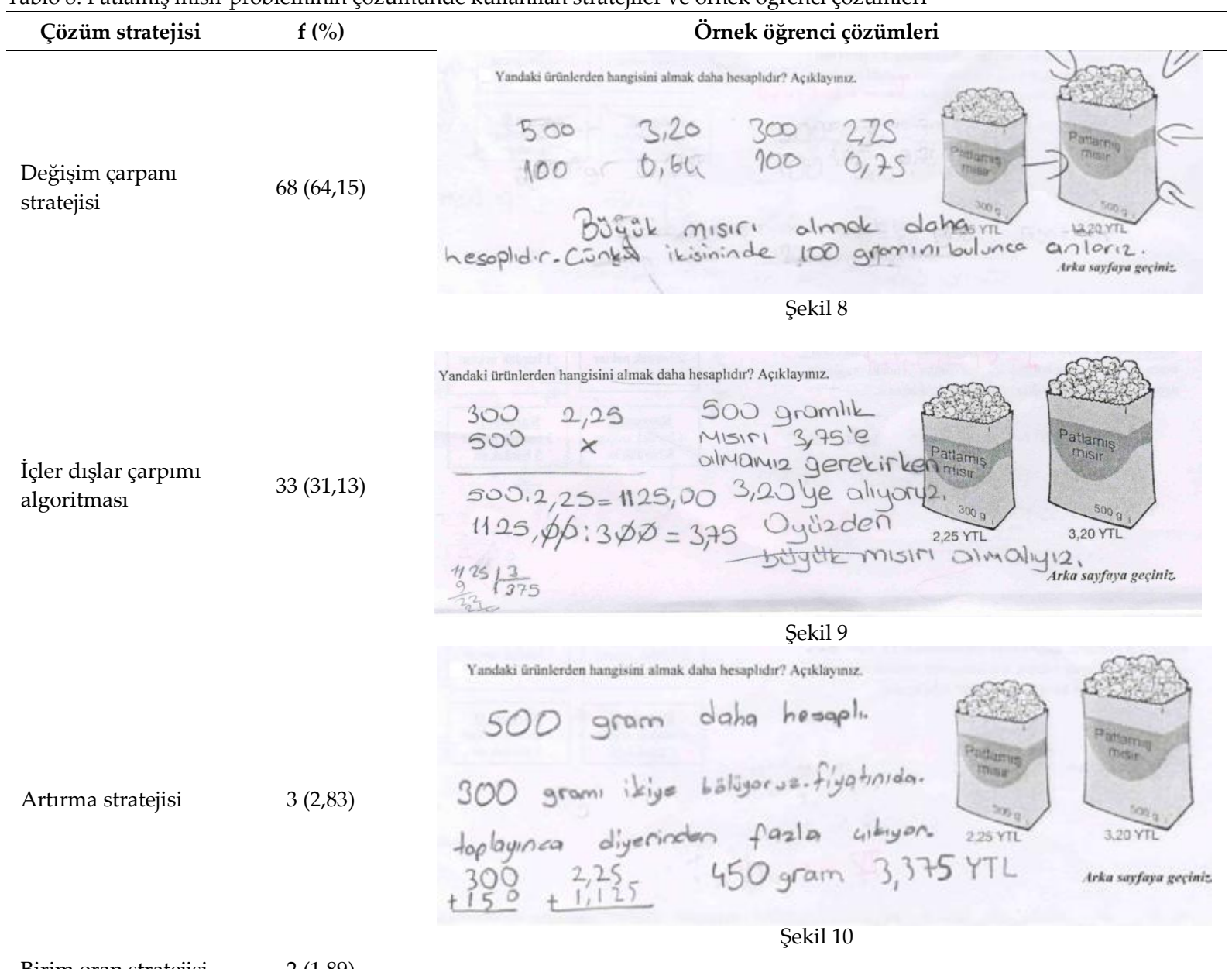




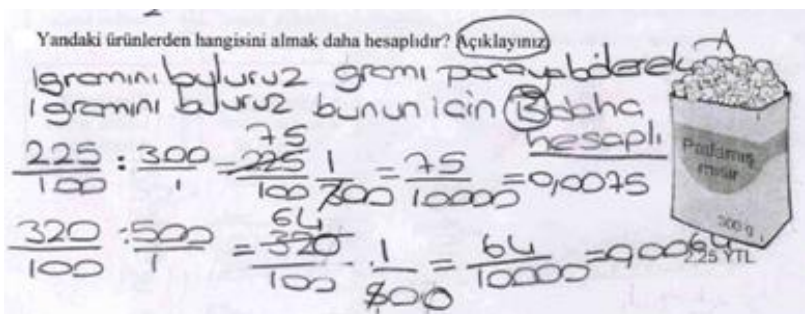

Şekil 11

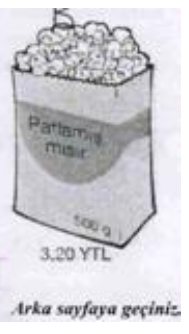

trka sayfaya gecinis

Toplam $106(100)$

Tablo 8 incelendiğinde öğrencilerin patlamış mısır problemini dört farklı strateji kullanarak çözdükleri görülmektedir. Öğrencilerin en sık kullandıkları iki strateji ilk iki soruda olduğu gibi değişim çarpanı stratejisi ve içler dışlar çarpımı algoritması olarak belirlenmiştir. Bu sorulardan farklı olarak patlamış mısır probleminde değişim çarpanı stratejisinin kullanımı içler dışlar çarpımı algoritmasının kullanımının iki katını geçmiştir. Artırma ve birim oran stratejileri az da olsa öğrenciler tarafından kullanılan diğer stratejilerdir.

Şekil 8'de problemin çözümü için iki ayrı değişim çarpanı belirlenmiştir. Büyük paket için 500 gram ile 100 gram arasında bir karşılaştırma yapılmış ve 500 gram 100 grama bölünerek değişim çarpanı 5 olarak belirlenmiştir. Daha sonra büyük paketin fiyatının değişim çarpanına bölünmesiyle bu paketin 100 gramı 0,64 TL olarak belirlenmiştir. Küçük paket için 300 gramlık patlamış mısır ile 100 gram arasında bir karşılaştırma yapılmış daha sonra 300 gram, 100 grama bölünerek değişim çarpanı 3 olarak belirlenmiştir. Son olarak da 300 gramlık mısırın fiyatının değişim çarpanına bölünmesi tercih edilmiştir $(2,25: 3=0,75)$. İki farklı ağırlıktaki patlamış mısırların fiyatlarını karşılaştırmak için ise bulunan sonuçlar karşılaştııılmıştır $(0,64<0,75)$. Bunun sonucunda 500 gramlık patlamış mısırın daha hesaplı olduğuna karar verilmiştir.

Şekil 9 biri ağırlık ile tanımlanmış diğeri fiyat ile tanımlanmış iki oranın eşitliği ile oluşturulmuş orantının formülleştirilmiş halini göstermektedir. Algoritmaya bağlı yapılan çözümlerde $\frac{300 \mathrm{gr}}{2,25 T L}=\frac{500 \mathrm{gr}}{x T L}$ orantısında bilinmeyen değer çapraz çarpım yapılarak bulunduğu görülmüştür.

Şekil 10'da aşă̆ıdaki şekilde çözüme gidilmiştir:

300 gram : $2,25 \mathrm{TL}$

150 gram : $1,125 \mathrm{TL}$

450 gram $=300$ gram +150 gram

450 gram $=2,25 \mathrm{TL}+1,125 \mathrm{TL}$

450 gram : 3,375 TL

Burada ikinci ürünün 450 gramlık miktarının TL cinsinden fiyatı bulunmuştur. İkinci ürünün 450 gramlık fiyatı ( 3,375 TL) ile 500 gram olan birinci ürünün fiyatı (3,20 TL) karşılaştırılmış ve birinci ürünün daha hesaplı olduğuna karar verilmiştir $(3,20<3,375)$.

Şekil 11'de görülen ürünleri kıyaslamak için her iki ürünün de birim miktarının fiyatı bulunmuştur. Yani her iki ürünün de 1 gramının fiyatı TL cinsinden bulunmuştur. Sonuca ulaşmak için ise birinci ürünün 1 gramlık fiyatı (0,0075 TL) ile ikinci ürünün 1 gramlık fiyatı $(0,0064 \mathrm{TL})$ karşılaştırılarak birinci ürünün daha hesaplı olduğu görülmüştür $(0,0064<0,0075)$.

Öğrencilerin dikdörtgen probleminin çözümünde kullandıkları stratejilere ait frekans ve yüzde değerleri ile örnek çözümleri Tablo 9'da sunulmuştur.

Tablo 9 incelendiğinde öğrencilerin dikdörtgen problemini üç farklı strateji kullanarak çözdükleri görülmektedir. Dikdörtgen probleminin çözümünde öğrencilerin onda sekizi içler dışlar çarpımı algoritmasını kullanmıştır. Bunun dışında değişim çarpanı ve denk kesirler stratejileri bu sorunun çözümünde öğrenciler tarafından kullanılan diğer stratejilerdir.

Şekil 12'de verilen çözüm biri dikdörtgenlerin kısa kenarları diğeri uzun kenarları ile tanımlanmış iki oranın eşitliği ile oluşturulmuş orantının formülleştirilmiş halini içermektedir. Öğrenciler cevaba bildikleri çapraz çarpım kuralını uygulayarak ulaşmaya çalışmışlardır. 
Şekil 13 incelendiğinde $\frac{2}{3}$ ile $\frac{3}{4}$ kesirlerinin birbirine denk olup olmadıkları araştırılmıştır. Birinci kesir $\frac{4}{4}$ ile ikinci kesir de $\frac{3}{3}$ ile çarpılmıştır. $\frac{2}{3} \cdot \frac{4}{4}=\frac{8}{12}$ ve $\frac{3}{4} \cdot \frac{3}{3}=\frac{9}{12}$ işlemleri ile $\frac{2}{3}$ ve $\frac{3}{4}$ kesirlerine denk kesirler elde edilmiştir. Yani $\frac{2}{3} \equiv \frac{8}{12}$ ve $\frac{3}{4} \equiv \frac{9}{12}$ olacak şekilde denk kesirler elde edilmiştir. Buradan da iki kesrin birbirine eşit olmadığından hareketle dikdörtgenlerin birbirine benzer olmadığı düşüncesine varılmıştır.

Tablo 9. Dikdörtgen probleminin çözümünde kullanılan stratejiler ve örnek öğrenci çözümleri

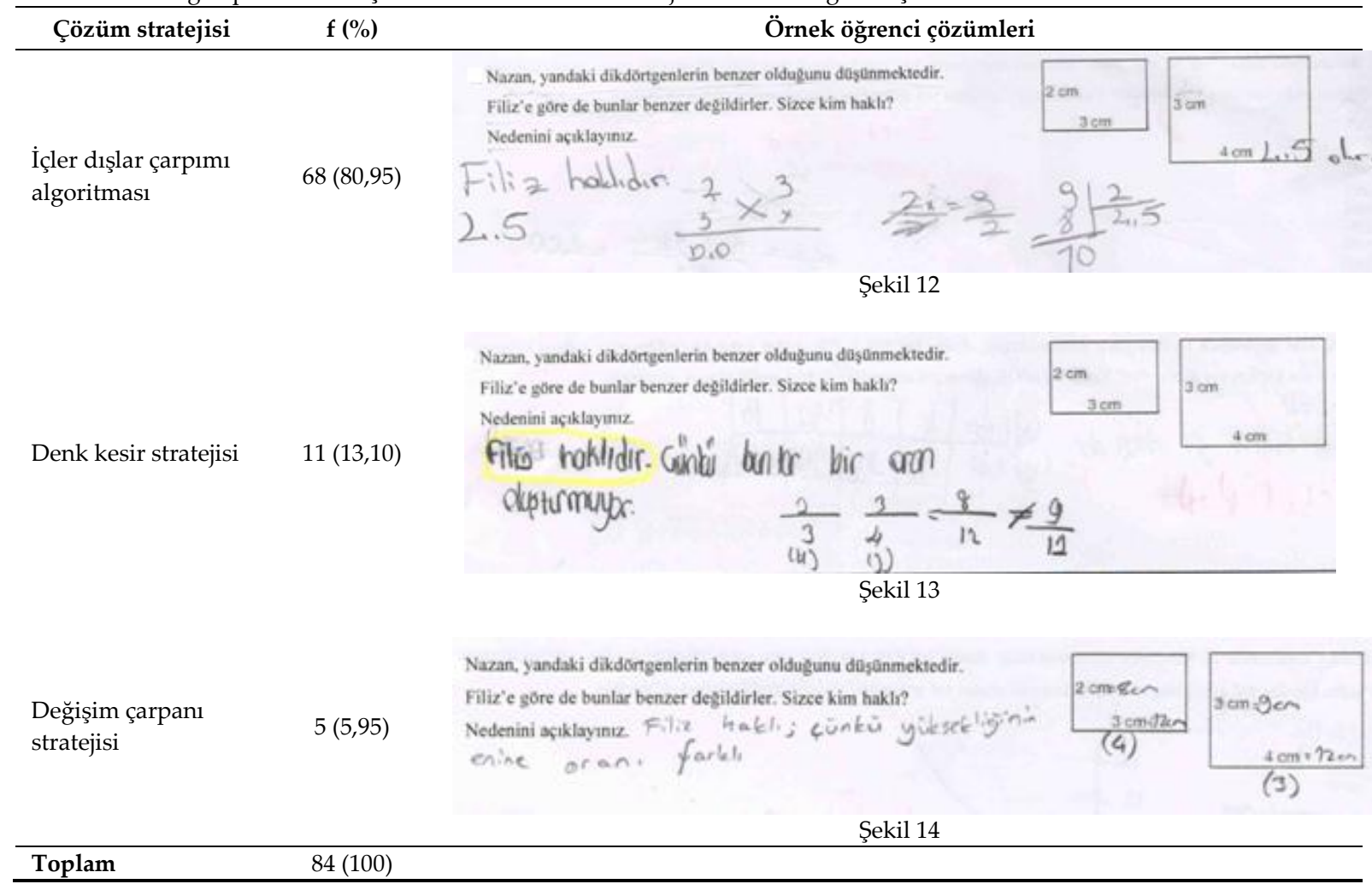

Şekil 14'te birinci dikdörtgenin kenar uzunlukları belirlenen değişim çarpanı (4) ile çarpılarak $8 \mathrm{~cm}$ ve $12 \mathrm{~cm}$ olacak şekilde yeni bir dikdörtgen elde edilmiştir. Benzer şekilde ikinci dikdörtgenin kenar uzunlukları belirlenen değişim çarpanı (3) ile çarpılarak $9 \mathrm{~cm}$ ve $12 \mathrm{~cm}$ olacak şekilde başka bir dikdörtgen elde edilmiştir. Bulunan yeni dikdörtgenlerin kenar uzunlukları birbiriyle aynı olmadı̆̆ için $(8 \neq 9)$ dikdörtgenlerin birbirine benzer olmadığı görüşüne varılmıştır.

Öğrencilerin karışım probleminin çözümünde kullandıkları stratejilere ait frekans ve yüzde değerleri ile örnek çözümleri Tablo 10'da sunulmuştur.

Tablo 10 incelendiğinde öğrencilerin karışım problemini üç farklı strateji kullanarak çözdükleri görülmektedir. Öğrencilerin yaklaşık \%90'ı her bir karışım için nektar miktarının su miktarına oranını bulmuşlar ve buldukları oranları karşılaştırmışlardır. Yani, öğrencilerin büyük çoğunluğu parça-bütün stratejisini kullanarak problemi çözmüşlerdir. Buna rağmen, çok az sayıda öğrenci her bir karışım için nektar miktarını toplam su ve nektar miktarına bölerek elde ettikleri oranları karşılaştırmışlardır. Diğer bir deyişle, karışım probleminin çözümünde parça-bütün stratejisi çok az sayıda öğrenci tarafından tercih edilmiştir. Benzer şekilde çok az sayıda öğrenci tarafından karşım problemi içler dışlar çarpımı algoritması kullanılarak çözülmüştür.

Şekil 15 değerlendirildiğinde probleminin çözümünde her bir karışımdaki bileşenler arasındaki orana odaklanıldığı görülmektedir. Diğer bir deyiş̧le nektar miktarları ile su miktarları oranlanmış ve bulunan oranlar arasında karşılaştırma yapılmıştır. A, B, C ve D karışımlarının parçaları arasındaki oranlar sırasıyla 
$\begin{array}{llll}2 & 1 & 4 & 3\end{array}$ $\frac{-}{3}, \frac{1}{4}, \frac{-}{8}, \frac{-}{5}$ olarak bulunmuş ve bu oranların ondalık sayı karşılıkları sırasıyla $0.66-0.50-0.25-0.60$ olarak

bulunmuştur. Son aşama olarak da bulunan ondalık sayılar sayısal olarak karşılaştırılmış, A karışımının en tatlı olduğuna karar verilmiştir.

Şekil 16 gözden geçirildiğinde problemin çözümünde her bir karışımda bileşenlerden yalnızca birinin miktarı ile bileşenlerin toplam miktarı arasındaki orana odaklanıldığı görülmektedir ( örneğin, 2 bardak nektar -2 bardak nektar +3 bardak su). A, B, C, ve D karışımlarındaki nektar miktarının nektar + su miktarına oranı sırasıyla $\frac{2}{5}, \frac{1}{5}, \frac{4}{12}, \frac{3}{8}$ olarak bulunmuştur ve bu oranların ondalık sayı karşılıkları sırasıyla $0.4-0.2-0.3-0.3$ olarak bulunmuştur. Son aşama olarak da bulunan ondalık sayılar sayısal olarak karşılaştırılmış, A karışımının en tatlı olduğuna karar verilmiştir.

Tablo 10. Karışım probleminin çözümünde kullanılan stratejiler ve örnek öğrenci çözümleri

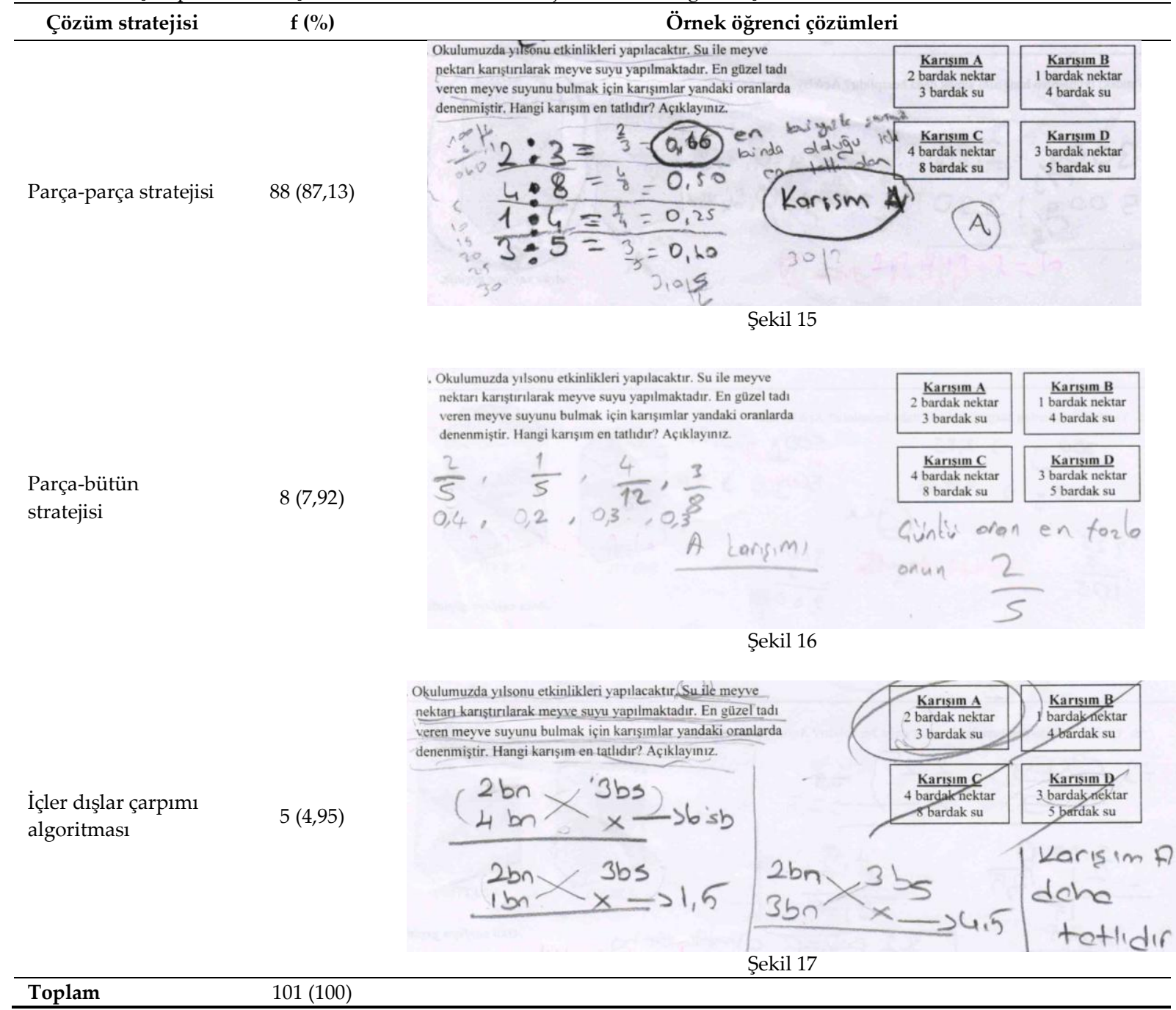

Şekil 17 incelendiğinde A karışımındaki 2 bardak nektar ile 3 bardak suyun referans alınarak diğer karışımlarla karşılaştırma yapıldığı görülmektedir. Problemin çözümünde biri nektar miktarı ile tanımlanmış diğeri su miktarı ile tanımlanmış iki oranın eşitliği ile oluşturulmuş orantının formülleştirilmiş halinden yararlanılmıştır. A karışımı ile aynı tadı veren B, C, ve D karışımlarındaki gerekli su miktarları hesaplanmış (sırasıyla 1,5 - 6-4,5) ve şekilde belirtilen B, C ve D karışımlarındaki su miktarları hesaplanan su miktarlarından fazla olduğu için $(4>1.5,8>6,5>4.5)$ en tatlı karışımın A karışımı olduğuna karar verilmiştir.

\section{Tartışma}


$\mathrm{Bu}$ araştırmada yedinci sınıf öğrencilerinin orantısal akıl yürütme gerektiren problemlerin çözümünde kullandıkları stratejileri belirlemek amaçlanmıştır. Bu amaçla öğrencilere beş açık uçlu sorudan oluşan orantısal akıl yürütme testi yöneltilmiştir. Testte yer alan yakıt problemi ve bayrak problemi bilinmeyen değeri bulma türünde olup patlamış mısır problemi, dikdörtgen problemi ve karışım problemi sayısal karşılaştırma türündedir. Araştırma sonucunda öğrencilerin orantısal akıl yürütme problemlerinin çözümünde sekiz farklı strateji kullandıklarını görülmüştür. Bu stratejiler içler dışlar çarpımı algoritması, değişim çarpanı stratejisi, parça - parça stratejisi, oran tablosu, artırma stratejisi, denk kesir stratejisi, birim oran stratejisi ve parça - bütün stratejisi olarak belirlenmiştir.

Öğrencilerin tüm problemlerde kullandıkları çözüm stratejileri değerlendirildiğinde en çok kullanılan stratejinin içler dışlar çarpımı algoritması olduğu görülmüştür. Bu bulgu alan yazındaki bazı çalışmalarla benzerlik göstermektedir (Akkuş-Çıkla ve Duatepe, 2002; Kayhan, 2005). Kayhan (2005) ilköğretim öğrencileri ile yaptığı araştırmanın sonucunda yedinci sını öğrencilerinin en çok kullandıkları stratejinin içler dışlar çarpımı algoritması olduğunu belirlemiştir. Buna ek olarak, bu algoritmanın yalnızca ilköğretim öğrencileri tarafından değil öğretmen adayları tarafından da sıklıkla kullanıldığı Akkuş-Çıkla ve Duatepe (2002) tarafından belirlenmiştir. Bu araştırmada içler dışlar çarpımı algoritmasının öğrenciler tarafından yaygın olarak kullanılmasında ders kitaplarının ve öğretmenlerin sınıf içi uygulamalarının etkili olduğu düşünülmektedir. Bu düşünceyi Cramer ve Post'un (1993) çalışması doğrular niteliktedir. Araştırmacılara göre ders kitaplarında bulunan problemler genelde içler dışlar çarpımı algoritmasının kullanımını gerektirmektedir. Bununla ilgili olarak Baykul (2009) “öğretim programında ve ders kitaplarında olduğu gibi, doğrudan orantının tanımını verip buna bir veya birkaç örnek verdikten sonra içler dışlar çarpımına dayalı işlemler ve problemler üzerinde çalışmak yerine, akıl yürütmeye ve sezgiye dayanan bir yola başvurmak yerinde olur" (s. 342) şeklinde öneride bulunmuştur. Buna ek olarak Slovin (2000) öğrencilerin orantısal akıl yürütme becerilerini geliştirmek için oran-orantı problemlerinde kullanılan bağlamın geleneksel yaklaşımdan çıkıp daha farklı stratejilerin kullanımına elverişli olması gerektiğini belirtmiştir.

İçler dışlar çarpımı algoritmasının yaygın olarak kullanıldığı problemlerden birisi yakıt problemidir ve bu problem bilinmeyen değer türündedir. Benzer şekilde, Valverde ve Castro (2012) araştırmasında bilinmeyen değer türünde bir problem kullanmış ve öğretmen adaylarının dörtte biri bu problemi çözmek için içler dışlar çarpımı algoritmasını kullanmışlardır. Araştırmacılar, içler dışlar çarpımı yardımıyla doğru sonuca ulaşan öğretmen adaylarının orantı sabitini kavramsal olarak anlayamadıklarını belirtmişlerdir. Araştırmacılar, bu tür tekniklerin uygulanmasının öğrencilerin algoritma yardımıyla problem çözmeye teşvik edildiği okul geleneklerinden kaynaklandığını dile getirmişlerdir.

Yakıt probleminin çözümünde içler dışlar çarpımı algoritması kadar çok olmasa da kullanılan diğer bir strateji değişim çarpanı stratejisi olmuştur. Bu stratejinin yaygın olarak kullanılmasında yakıt miktarları arasında tam kat bir ilişki olması (4 litre - 16 litre) ve bu ilişkinin öğrenciler tarafından kolayca fark edilmesinden kaynakladığı düşünülmektedir. Ben-Chaim vd. (1998) orantı problemindeki sayılar arasında bir kat ilişkisi olduğunda öğrencilerin değişim çarpanı stratejisini daha sık kullandığını belirtmiştir. Bu ifade yakıt probleminde değişim çarpanının kullanım sıklığını açıklar niteliktedir.

Çalışmaya katılan öğrencilerin yaklaşık onda biri yakıt problemini çözmek için oran tablolarından yararlanmıştır. Öğrenciler yakıt miktarı ile uzaklığa ait değerleri göstermek için tablo oluşturmuşlar ve bu değerlerle eş zamanlı işlemler yaparak yakıt miktarı ile uzaklığın aralarında orantılı olduğunu fark etmişlerdir. Bu tarz bir kullanım, Dole'nin (2008) orantısal akıl yürütmeyi geliştirmede oran tablolarının nasıl kullanılması gerektiğine yönelik tavsiyeleriyle uyuşmaktadır. Oran tabloları ile ilgili olarak beşinci sınıf matematik öğretim programında "tablo kullanarak oran problemlerini çözer ve kurar" (MEB, 2009, s. 281) kazanımı yer almaktadır. Benzer şekilde altıncı sınıf matematik öğretim programında orantı tablosundaki örüntüler yardımıyla doğru orantının keşfettirilmesine yönelik vurgu yapılmaktadır. Bu çalışmada öğrencilerin oran tablosu kullanımları öğretmenlerin programda ifade edilen kazanımları sınıf içinde uygulamaları ile ilişkilendirilebilir.

Artırma stratejisi ve birim oran stratejisi az da olsa yakıt probleminin çözümünde öğrenci tarafından tercih edilmiştir. Hart'a (1984) göre artırma stratejisi bir oran oluşturmayı ve bu oranı toplama-çıkarma yoluyla ikinci bir orana genişletmeyi içermektedir. Lamon (2012) artırma stratejisinin ilkel bir strateji 
olduğunu ve bu stratejinin temelinde örüntü tanıma ve replikasyon yoluyla istenilen niceliğe ulaşıncaya kadar ileriye akıl yürütme süreci olduğunu belirtmiştir. Yakıt probleminde artırma stratejisinin nadiren kullanılmasında öğrencilerin toplamsal akıl yürütme düzeyinden daha ileri düzeyde düşünüyor olmaları etkili olmuş olabilir. Yani, bu araştırmada öğrenciler problemleri çözerken daha çok çarpımsal akıl yürütme gerektiren stratejileri kullanmış olabilirler. Ben-Chaim, Keret ve Ilany (2012) artırma ve birim oran stratejilerinin formal öğretim öncesinde yaşam tecrübesine dayalı içgüdüsel olarak kullanıldığına işaret etmişlerdir. Diğer bir deyişle, birim oran stratejisi kendi kendilerine strateji geliştiren öğrencilerde doğal olarak ortaya çıkmaktadır (Ben-Chaim vd., 1998). Kısaca, yakıt probleminde çözümünde artırma ve birim oran stratejilerinin az olarak kullanılmasında formal eğitimin etkili olduğu düşünülmektedir. Yani öğrenciler, oran orantı konusunu öğrendikten sonra artırma ve birim oran gibi sezgisel stratejileri kullanmak yerine formül kullanmayı gerektiren formal stratejileri tercih etmiş olabilirler.

Bayrak problemi de yakıt problemi gibi bilinmeyen değer türünde bir problem olup testin genelinde içler dışlar çarpımı algoritması en fazla bu problemde kullanılmıştır. Daha ayrıntılı olarak, bu problemi doğru şekilde çözen öğrencilerin yaklaşık \% 90'ı içler dışlar çarpımı algoritmasını tercih etmişlerdir. Geriye kalan öğrenciler ise değişim çarpanı stratejisini kullanmışlardır. Bu problemde değişim çarpanı stratejisi kullanımı yakıt problemindekine göre önemli ölçüde azalmıştır. Bu azalmada değişim çarpanının tam sayı değer almaması etkili olmuş olabilir. Bayrak direği ile gölgesi arasında tam kat bir ilişki olmadığı için yakıt probleminde değişim çarpanı stratejisini kullanan öğrenciler bu problemde içler dışlar çarpımı algoritmasını tercih etmiş olabilirler. Bu düşünceyi Heller, Post, Behr ve Lesh (1989) ve Lawton (1993)'un strateji kullanma sebeplerine yönelik yapmış olduğu çalışmalar doğrular niteliktedir. Bu çalışmalarda nicelikler arasında kat ilişkisi olmaması değişim çarpanının daha az tercih edilmesinde etkili olduğu ifade edilmiştir.

Patlamış mısır problemi sayısal karşılaştırma türünde bir problemdir. Bu problemde öğrenciler tarafından en fazla kullanılan stratejiler değişim çarpanı stratejisi ve içler dışlar çarpımı algoritması olmuştur. Yakıt problemi ve bayrak probleminin tersine, değişim çarpanı stratejisini kullananların sayısı içler dışlar çarpımı algoritmasını kullananların sayısından çok daha fazla olmuştur. Böyle bir sonucun bulunması muhtemeldir. Çünkü büyük ve küçük mısır paketlerinin fiyatları ondalık sayı biçiminde verildiği için içler dışlar çarpımı algoritmasının kullanımını bu problemin çözümünü zorlaştırmıştır. Öğrenciler ondalık sayılarla çarpma ve bölme işlemleri yapmak yerine değişim çarpanı stratejisi yardımıyla daha kolay bir şekilde çözüme ulaşmayı tercih etmiş olabilirler. Valverde ve Castro (2012) problem çözümünde değişim çarpanı stratejisi kullanarak doğru cevaba ulaşan öğrencilerin orantısal akıl yürütme sürecinin en üst düzeyinde olduğunu belirtmiştir. Buradan hareketle bu problemde değişim çarpanı stratejisini kullanan öğrencilerin iki mısır paketi arasındaki çarpımsal ilişkiyi görebildikleri ve orantısal akıl yürütmenin en üst düzeyinde bulundukları söylenebilir. Son olarak çok az sayıda öğrenci bu problemi artırma ve birim oran stratejilerini kullanarak çözüme gitmiştir. Bu problemde mısır paketlerinin birer gramını bularak çözüme gitmek daha fazla işlemsel iş yükü getirdiğinden dolayı öğrencilerin birim oran stratejisini daha az tercih ettiği düşünülmektedir.

Dikdörtgen problemi, patlamış mısır problemi gibi sayısal karşılaştırma türünde bir problem olmasına rağmen patlamış mısır probleminde öğrencilerin çoğunluğu değişim çarpanı stratejisini tercih ederken bunun aksine öğrenciler dikdörtgen probleminde içler dışlar çarpımı algoritmasını çok daha fazla tercih etmişlerdir. Dikdörtgen probleminde en boy uzunlukları küçük tam sayı değerler aldığı için içler dışlar çarpımı algoritmasını uygulamak patlamış mısır probleminde ondalık sayıları kullanarak içler dışlar çarpımı algoritmasını uygulamaktan daha kolay olmuş olabilir. Dolayısıyla patlamış mısır probleminin çözümünde değişim çarpanı stratejisini kullanan öğrenciler, dikdörtgen probleminde içler dışlar çarpımı algoritmasını tercih etmiş olabilirler. Çetin ve Ertekin (2011) öğretmenlerin oran-orantı öğretiminde en sık kullandıkları stratejinin içler dışlar çarpımı algoritması olduğunu ifade etmiştir. Buradan öğretmenlerin oran-orantı konusunun öğretiminde kullandıkları stratejilerin öğrencilerin strateji tercihlerini etkilemiş olabileceği ve öğrencilerin değişim çarpanı gibi sezgisel stratejilerden formal stratejilere yöneldikleri söylenebilir. Van de Van de Walle, Karp ve Bay-Williams (2013)içler dışlar çarpımı algoritması gibi sembolik ya da mekanik yöntemlerin öğrencilere ancak sezgisel ve kavramsal yöntemlerle yeterince deneyim kazanıldıktan sonra öğretilmesi gerektiğini vurgulamıştır.

Denk kesir stratejisi dikdörtgen probleminin çözümünde nadir olarak kullanılmıştır. Denk kesir stratejisini kullanan öğrenciler iki dikdörtgenin benzer olup olmadığını anlamada gerekli olan çarpımsal 
ilişkiyi fark edebilmişlerdir. Ercole, Frantz ve Ashline (2011) denk kesir stratejisinin öğrencilerin kesir bilgilerini oran bilgisine ilişkilendiren bir strateji olduğunu ve kesir kavramı ile orantı kavramı arasında bir geçiş aşaması sağladığını belirtmişlerdir. Aslında her bir dikdörtgenin kendi içindeki en-boy oranı ya da dikdörtgenler arası en-boy oranları benzerlik oranını vermektedir ve bu oran aynı zamanda orantı sabitine karşılık gelmektedir (Lamon, 2012). Denk kesir stratejisi öğrencilerin kesir, oran, orantı kavramlarını ilişkilendirmelerini gerektirmektedir. Öğrenciler, bu problemin çözümünde denk kesir stratejisi gibi kavramsal bir strateji kullanmak yerine işlem ağırlıklı içler dışlar algoritmasını tercih etmiş olabilirler.

Karışım problemi sayısal karşılaştırma türünde bir problem olup bu problemde patlamış mısır ve dikdörtgen probleminden farklı olarak öğrencilerden aynı anda dört oranı birbirleriyle karşılaştırmaları istenmiştir. Bu problemin çözümünde parça-parça stratejisi çok fazla tercih edilirken parça-bütün stratejisi ve içler dışlar çarpımı algoritması az da olsa kullanılan diğer stratejiler arasında olmuştur. Bunun bir sebebi olarak parça-parça ve parça-bütün stratejilerinin bu problemin çözümü için diğerlerinden daha uygun olması olabilir. Örneğin içler dışlar çarpımı algoritmasını bu problemin çözümünde kullanması durumunda öğrencinin bu algoritmayı $3 \mathrm{kez}$ uygulaması ve bulduğu sonuçları karşılaştırması gerekmektedir. Aynı şekilde artırma ve değişim çarpanı stratejilerinin bu problemin çözümünde kullanılması daha fazla işlem yükü getirmektedir. Dolayısıyla öğrenciler daha uygun stratejilerden biri olan parça-parça stratejisine yönelmişlerdir. Öte yandan, diğer problemlerin çözümünde kullanılan denk kesir ve birim oran stratejileri bu problemin çözümü için uygun stratejiler olmalarına rağmen öğrenciler tarafından tercih edilmemiştir. Bunun sebebi olarak öğrencilerin dört oranın karşılaştırıldı̆̆ı problem durumlarıyla daha önce hiç karşılaşmamış olabilecekleri düşünülmektedir.

Özetlemek gerekirse bu araştırmanın sonucunda öğrencilerin orantısal akıl yürütme problemlerinin çözümünde içler dışlar çarpımı algoritması, parça-parça ve değişim çarpanı stratejilerini yaygın olarak kullandıkları görülmüştür. Diğer taraftan, öğrencilerin oran tablosu, artırma, denk kesir, birim oran ve parça-bütün stratejilerini daha az kullandığı görülmüştür. Fakat testin genelinde öğrenciler tarafından en yaygın olarak kullanılan strateji içler dışlar çarpımı algoritması olmuştur. Bu strateji öğrencilerin kavramsal düşünme yerine prosedürel bilgiyi kullanmalarını teşvik etmektedir. İçler dışlar çarpımı algoritması gibi mekanik yöntemlerin öğrencilere ancak sezgisel ve kavramsal yöntemlerle yeterince deneyim kazanıldıktan sonra öğretilmesi gerekmektedir. Öğrenciler tarafından farklı stratejilerin kullanılmasında öğretmenlerin oran-orantı kavramları öğretilirken aktif rol almaları gerekmektedir. Yani, öğrencilerin kavramsal stratejileri öğrenebilmesi için öğretmenlerin mümkün olduğunca çok sayıda orantısal akıl yürütme stratejisinden ve bu stratejilerin sınıf ortamında nasıl kullanılması gerektiğinden haberdar olarak bunu konunun öğretimine yansıtmaları gerekir. Ayrıca yedinci sınıf öğrencilerinin strateji kullanımlarında daha bilinçli olmalarını sağlamak için onlara çok sayıda stratejinin kullanılarak oran-orantı kavramlarının öğretildiği ders kitapları temin edilebilir. Bunun sağlanabilmesi için oran-orantı kavramlarını sunarken yazarların ders kitabında yer verdiği çözümlü örnekler farklı stratejilerin kullanıldığı birden fazla yolla çözülmelidir. Ayrıca, ders kitabındaki orantısal akıl yürütme gerektiren alıştırma soruları farklı çözüm yollarına uygun olacak şekilde tasarlanmalıdır.

\section{Kaynakça}

Akkuş- Çıkla, O. ve Duatepe, A. (2002). İlköğretim matematik öğretmen adaylarının orantısal akıl yürütme becerileri üzerine niteliksel bir çalışma. Hacettepe Üniversitesi Ĕ̆itim Fakültesi Dergisi, 23, 32-40.

Akkuş,O. ve Duatepe-Paksu, A. (2006). Orantısal akıl yürütme becerisi testi ve teste yönelik dereceli puanlama anahtarı geliştirilmesi. Eurasian Journal of Educational Research, 25, 1-10.

Allain, A. (2000). Development of an instrument to measure proportional reasoning among fast-track middle school students. Unpublished master's thesis, University of North Carolina State, Raleigh.

Aygün, S. Ç., Aynur, N., Çuha, S. S., Karaman, U., Özçelik, U., Ulubay, M. ve Ünsal, N. (2011a). İlköğretim matematik 7 ders kitabı. Ankara: Devlet Kitapları Müdürlüğü.

Aygün, S. Ç., Aynur, N., Çuha, S. S., Karaman, U., Özçelik, U., Ulubay, M. ve Ünsal, N. (2011b). İlköğretim matematik 7 çalışma kitabı. Ankara: Devlet Kitapları Müdürlüğü. 
Bart, W., Post, T., Behr, M., \&Lesh, R. (1994). A diagnostic analysis of a proportional reasoning test item: An introduction to the properties of a semi-dense item. Focus on Learning Problems in Mathematics,16(3), 111.

Baykul, Y. (2009). Ilköğretimde matematik öğretimi: 6.-8.sınıflar. Ankara: Pegem A Yayıncılık.

Ben-Chaim, D., Fey, J. T., Fitzgerald, W. M., Benedetto, C., \& Miller, J. (1998). Proportional reasoning among $7^{\text {th }}$ grade students with different curricular experiences. Educational Studies in Mathematics, 36, $247-273$.

Ben-Chaim, D., Keret, Y., \&Ilany, B. S. (2012). Proportional reasoning - A psychological-didactical view. In D. Ben-Chaim, Y. Keret, \& B. S. Ilany (Eds.), Ratio and proportion: Research and teaching in mathematics teachers' education (pre- and in-service mathematics teachers of elementary and middle school classes) (pp. 4960). Rotterdam: SensePublishers.

Boyer, T. W., Levine, S. C., \&Huttenlocher, J. (2008). Development of proportional reasoning: Where young children go wrong. Developmental Psychology, 44(5), 1478-1490.

Büyüköztürk, Ş., Çakmak, E. K., Akgün, Ö. E., Karadeniz, Ş., ve Demirel, F. (2009). Bilimsel araştırma yöntemleri (4. bs.). Ankara: Pegem-A Yayıncılık.

Clark, K. \&Lesh, R. (2003). Whodunit? Exploring proportional reasoning through the footprint problem. School Science and Mathematics, 103(2), 92-98.

Cramer, K. \& Post, T. (1993). Connecting research to teaching proportional reasoning. Mathematics Teacher, 86(5), 404- 407.

Cramer, K., Post, T., \& Currier, S. (1993). Learning and teaching ratio and proportion: Research implications. In D. Owens (Ed.), Research ideas for the classroom (pp. 159- 178). NY: Macmillan Publishing Company.

Creswell, J. W. (2012). Educational research: Planning, conducting, and evaluating quantitative and qualitative research (4th ed.). Boston: Pearson.

Crocker, L. \&Algina, J. (2006). Introduction to classical and modern test theory. Mason, OH: Cengage Learning.

Çetin, H. \& Ertekin, E. (2011). The relationship between eighth grade primary school students' proportional reasoning skills and success in solving equations. International Journal of Instruction, 4(1), 47-62.

DeVellis, R. F. (2003). Scale development: Theory and applications (2nd ed.). Thousand Oaks, California: Sage.

Dole, S. (2008). Ratio tables to promote proportional reasonings in the primary classroom. Australian Primary Mathematics Classroom, 13(2), 18-22.

Duatepe, A., Akkuş-Çıkla, O. ve Kayhan, M. (2005). Orantısal akıl yürütme gerektiren sorularda öğrencilerin kullandıkları çözüm stratejilerinin soru türlerine gore değişiminin incelenmesi. Hacettepe Üniversitesi Ĕ̆itim Fakültesi Dergisi, 28, 73-81.

Ercole, L. K.,Frantz, M., \&Ashline, G. (2011). Multiple ways to solve proportions. MathematicsTeaching in the Middle School, 16(8), 482-490.

Flowers, J. (1998). A study of proportional reasoning as it relates to the development of multiplication concepts. Unpublished doctoral dissertation, The University of Michigan, Michigan.

Fujmura, N. (2001). Facilitating children's proportional reasoning: A model of reasoning processes and effects of intervention on strategy change. Journal of Educational Psychology, 93, 589-603.

Fuson, K. C., \& Abrahamson, D. (2005). Understanding ratio and proportion as an example of the apprehending zone and conceptual-phase problem-solving models. In J. Campbell (Ed.), Handbook of mathematical cognition (pp. 213-234). New York: Psychology Press.

Hart, K. M. (1984). Ratio: Children's strategies and errors. Windsor, England: NFER-NELSON Publishing Company.

Heller, P., Post, T., Behr, M., \& Lesh, R. (1989). Proportional reasoning: The effect of two context variables, rate type and problem setting. JournalforResearch in ScienceTeaching, 26(1), 205-220. 
Hillen, A. F. (2005). Examining preservice secondary mathematics teachers' ability to reason proportionally prior to and upon completion of a practice-based mathematics methods course focused on proportional reasoning. Unpublished doctoral dissertation, University of Pittsburgh, United States of America.

Hines, E. \& McMahon, M. T. (2005). Interpreting middle school students' proportional reasoning strategies: Observations from preservice teachers. School Science and Mathematics, 105(2), 88-105.

Hopkins, K. D. (1998). Educational and psychological measurement and evaluation (8th ed.). Boston: Allyn \& Bacon.

Judd, C., Smith, E., \& Kidder, L. (1991). Research methods in social relations (6th ed.). Fort Worth et al.: Harcourt Brace Jonavovich College Publishers.

Kayhan, M. (2005). 6. ve 7. Sını öğrencilerinin oran-orantı konusuna yönelik çözüm stratejilerinin; sınıf düzeyine, cinsiyete ve soru tipine gore değişiminin incelenmesi.Yayınlanmamış yüksek lisans tezi, Hacettepe Üniversitesi, Ankara.

Lamon, S. J. (2007). Rational numbers and proportional reasoning: Toward a theoretical framework for research. In F. K. Lester, Jr. (Ed.), Second handbook of research on mathematics teaching and learning (pp. 629-668). NC: Information Age Publishing.

Lamon, S. J. (2012). Teaching fractions and ratios for understanding: Essential content knowledge and instructional strategies for teachers ( $3^{\text {rd }}$ ed.). New York: Routledge

Lappan, G., Fey, J. T., Fitzgerald, W. M., Friel, S. N., \& Phillips, E. (2006). Comparing and scaling: Ratio, proportion and percent. Boston, MA: Prentice Hall.

Lawton C. A. (1993). Contextual factors affecting errors in proportional reasoning. Journal for Research in Mathematics Education, 24(5), 460-466.

Lesh, R., Post, T., \& Behr, M. (1988). Proportional reasoning. In J. Hiebert and M. Behr (Eds.), Number concepts and operations in the middle grades (pp. 93-118). Reston, VA: National Council of Teachers of Mathematics.

Levin-Weinberg, S. (2002). Proportional reasoning: One problem, many solutions!. In B. Litwiller (Ed.), Making sense of fractions, ratios, and proportions (pp. 138-144). Reston, VA: National Council of Teachers of Mathematics.

Milli Eğitim Bakanlığı (2009). İlköğretim matematik dersi 6-8.stmıflar öğretim programı. Ankara: Devlet Kitapları Müdürlüğü.

National Council of Teachers of Mathematics (NCTM). (2000). Principles and standards for school mathematics. Reston, VA: NCTM Publications.

National Research Council (NRC). (2001). Adding it up: Helping children learn mathematics. In J. Kilpatrick, J. Swafford, \& B. Findell (Eds.), Mathematics learning study committee, center for education, division of behavioral and social sciences and education. National Academy Press: Washington, DC.

Pallant, J. (2007). SPSS survival manual: A step by step guide to data analysis using SPSS for Windows. Maidenhead: Open University Press.

Parker, M. (1999). Building on " building up": Proportional-reasoning activities for future teachers. Mathematics Teaching in The Middle School, 4(5), 286- 289.

Post, T. R., Behr, M. J., \&Lesh, R. (1988). Proportionality and the development of prealgebra understandings. In A. Coxford\& A. Shulte (Eds.), The ideas of algebra, K-12 (pp. 78-90). Reston, VA: National Council of Teachers of Mathematics.

Singh, P. (2000). Understanding the concepts of proportion and ratio constructed by two grade six students. Educational Studies in Mathematics, 43(3), 271-292.

Slovin, H. (2000). Moving to proportional reasoning. Mathematics Teaching in the Middle School, 6(1), 58-60. 
Sowder, J., Armstrong, B., Lamon, S., Simon, M., Sowder, L., \& Thompson, A. (1998). Educating teachers to teach multiplicative structures in the middle grades. Journal of Mathematics Teacher Education, 1, 127155.

Umay, A. (2003). Matematiksel muhakeme yeteneği, Hacettepe Üniversitesi Ĕ̆itim Fakültesi Dergisi, 24, 234243.

Umay, A. veKaf, Y. (2005). Matematikte kusurlu akıl yürütme üzerine bir çalışma. Hacettepe Üniversitesi Eğitim Fakültesi Dergisi, 28, 188-195.

Valverde, G. \& Castro, E. (2012). Prospective elementary school teachers' proportional reasoning. PNA, 7(1), $1-19$.

Van de Walle, J. A.,Karp, K. S., \& Bay-Williams, J. M. (2013). Elementary and middleschool mathematics: Teaching developmentally ( $8^{\text {th }}$ ed.). New York, NY: Pearson Education.

Vergnaud, G. (1983). Multiplicative structures. In R. Lesh\& M. Landau (Eds.), Acquisition of mathematical concepts and processes (pp. 127-74). Orlando, FL: Academic Press. 